\title{
The Role of the Melanocortin System in Metabolic Disease: New Developments and Advances
}

\author{
Jennifer W. Hill Latrice D. Faulkner \\ Department of Physiology and Pharmacology, College of Medicine, The University of Toledo, Toledo, $\mathrm{OH}, \mathrm{USA}$
}

\section{Keywords}

Melanocortin system · Metabolic disease - Obesity

\begin{abstract}
Obesity is increasing in prevalence across all sectors of society, and with it a constellation of associated ailments including hypertension, type 2 diabetes, and eating disorders. The melanocortin system is a critical neural system underlying the control of body weight and other functions. Deficits in the melanocortin system may promote or exacerbate the comorbidities of obesity. This system has therefore generated great interest as a potential target for treatment of obesity. However, drugs targeting melanocortin receptors are plagued by problematic side effects, including undesirable increases in sympathetic nervous system activity, heart rate, and blood pressure. Circumnavigating this roadblock will require a clearer picture of the precise neural circuits that mediate the functions of melanocortins. Recent, novel experimental approaches have significantly advanced our understanding of these pathways. We here review the latest advances in our understanding of the role of melanocortins in food intake, reward pathways, blood pressure, glucose control, and energy expenditure. The evidence suggests that downstream melanocortin-responsive circuits respon-
\end{abstract}

\begin{tabular}{ll}
\hline KARGER & $\begin{array}{l}\text { ( 2016 The Author(s) } \\
\text { Published by S. Karger AG, Basel }\end{array}$ \\
$\begin{array}{l}\text { E-Mail karger@karger.com } \\
\text { www.karger.com/nen }\end{array}$ & $\begin{array}{l}\text { This article is licensed under the Creative Commons Attribution- } \\
\text { NonCommercial-NoDerivatives 4.0 International License (CC BY- } \\
\text { NC-ND) (http://www.karger.com/Services/OpenAccessLicense) } \\
\text { Usage and distribution for commercial purposes as well as any dis- } \\
\text { tribution of }\end{array}$
\end{tabular}

sible for different physiological actions do diverge. Ultimately, a more complete understanding of melanocortin pathways and their myriad roles should allow treatments tailored to the mix of metabolic disorders in the individual patient.

(c) 2016 The Author(s)

Published by S. Karger AG, Basel

\section{Introduction}

Obesity is increasing in prevalence across all sectors of society, and is now considered to be a global epidemic. Nearly $35 \%$ of adults in the USA are obese [1], with $6.3 \%$ of the population being severely obese [2]. Obesity is associated with a constellation of serious disorders, including hypertension [3], type 2 diabetes [3], and depression [4]. Given these links, it is not surprising that obesity is also associated with higher all-cause mortality [5]; estimates for the annual number of excess deaths attributable to obesity in the USA vary from 111,909 to $365,000[6,7]$. These facts have sparked intensive research into the causes and consequences of obesity.

The modern era of obesity research is only 20 years old, dating from the discovery of the adipokine leptin and leptin-responsive neurons in the brain $[8,9]$. Arguably, the most critical neural system identified to date underly- 
ing the control of body weight is the melanocortin system. In fact, the melanocortin system may contribute to the development or severity of many health problems associated with obesity, including hypertension, type 2 diabetes, and eating disorders. Gaining a complete understanding of the function of the melanocortin system is therefore critical.

In the past decade, conditional knockout strategies have been used to delete melanocortin-related genes in targeted neuronal populations. However, observational studies and simple gene knockout experiments have drawbacks. For instance, altering gene expression may not affect neuronal activity. In addition, functional redundancies and rewiring of neurocircuitry due to genetic manipulation may present a misleading picture of the importance of the targeted gene.

Recent, novel experimental approaches are changing our picture of the melanocortin system along with our understanding of brain function generally. Technologies developed within the past 5 years, such as optogenetics and the chemogenetic "designer receptors exclusively activated by designer drugs" (DREADD) system, are helping to establish a causal relationship between cellular activity in the brain and physiological responses [10-12]. These techniques allow an investigator to turn on or off specific cell populations acutely using genetic manipulation and either photostimulation (optogenetics) or pharmacotherapy (DREADD). In addition, new techniques to visualize and record neuronal activity in awake, behaving animals are revealing a previously unappreciated complexity in the function of neurons in vivo. It is now possible to do extracellular recording from multiple neurons simultaneously using an optic fiber-coupled multielectrode probe (or "optetrode") introduced into a targeted nucleus of the brain [13]. This technology is particularly powerful in conjunction with the optogenetic identification of neuron types. Alternatively, neuronal activity can be monitored following the introduction of a calcium-sensitive, fluorescent reporter. A fiber-optic probe may then be used to record changes in the fluorescence of a neuronal population, or the fluorescence of individual neurons can be recorded with a lens attached to a miniature microscope mounted on the head of the animal (e.g., a mouse).

In some cases, findings from studies using these modern techniques contrast with the effect of gene ablation, providing new information on how the melanocortin system functions. These approaches have also been complemented by more sophisticated genetic approaches that allow gene deletion or reactivation at the time and location of an investigator's choosing. Using this new in-

The Role of the Melanocortin System in Metabolic Disease formation, we are beginning to develop a larger, more integrated view of the function of the melanocortin system.

\section{The Melanocortin System}

Melanocortins, of which $\alpha-\mathrm{MSH}$ is a classic example, are products of the proopiomelanocortin (POMC) gene. The brain's melanocortin system consists of the neurons that express POMC, the central nervous system (CNS) circuits that sense melanocortins, and the neurons that produce agouti-related peptide (AgRP), an endogenous antagonist of melanocortins [14]. Two recognized neuronal populations expressing POMC exist in the brain, although low levels of POMC mRNA have been reported in other CNS regions [15-17]. A small population resides in the nucleus of the solitary tract (NTS) in the brainstem [18]. The second, largest population resides in the hypothalamus, specifically in the arcuate nucleus (ARC), and coexpresses cocaine- and amphetamine-regulated transcript [18]. Note that this population is not homogeneous. Subpopulations of these neurons express GABA, glutamate, and various receptors; these subgroups may project to different areas and serve different functions [19-22]. In addition, POMC neurons may also exhibit age-dependent changes in amino acid phenotype [23].

The 5 melanocortin receptors (MC1R to MC5R) were named in the order of their cloning. MC3R and MC4R are considered the neural melanocortin receptors (MCRs), due to their high expression in the brain [24-28]. MC4Rs show a broader expression pattern than MC3Rs, being found in around 100 brain nuclei.

The highest expression of MC4Rs is seen in the hypothalamus and the brainstem. Second-order neurons in the hypothalamus expressing MC4Rs that have been identified to date include oxytocin, thyrotropin-releasing hormone (TRH), and corticotrophin-releasing hormone synthesizing neurons in the paraventricular nucleus of the hypothalamus (PVH) $[28,29]$. Several brainstem regions that receive direct projections from POMC neurons of the ARC also express MC4Rs. These include sympathetic preganglionic neurons in the intermediolateral cell column (IML) $[18,30]$, the dorsal motor nucleus of the vagus (DMV), which contains parasympathetic preganglionic cells, and the NTS, which controls output from DMV cells [31]. MC4R agonists directly inhibit the activity of parasympathetic preganglionic neurons in the DMV and excite the activity of sympathetic preganglionic neurons in the IML [32]. 
MC3Rs are restricted to the hypothalamus and limbic structures. The highest expression levels occur in the ARC, ventromedial hypothalamus, ventral tegmental area (VTA), and medial habenula [24]. Interestingly, the MC3R is the only MCR expressed by POMC and AgRP/ neuropeptide Y (NPY) neurons in the ARC $[33,34]$. These MC3Rs allow melanocortins to act pre- and postsynaptically to reduce POMC neuronal activity, forming an "ultrashort" autoinhibitory feedback loop [34-36].

MCRs are G protein-coupled receptors with a high level of constitutive activity [37]. Receptor activation can ultimately increase neuronal excitability, facilitate neurotransmitter release, regulate how neurons integrate synaptic input, and alter synaptic strength and connectivity $[38,39]$. For instance, MC4Rs can increase the amount of GABA released by neurons projecting to the $\mathrm{PVH}$. The MC4R is located on the terminals of axons in the PVH [40]. $\alpha-M S H$ was found to potentiate GABA-mediated responses in PVH neurons by acting presynaptically; in addition, the action of $\alpha-\mathrm{MSH}$ was blocked by AgRP [40]. The ability to alter synaptic strength may play a role in many functions of melanocortins, including their influence on body weight and reward pathways [41]. However, when stimulated continuously, the MC4R undergoes desensitization and internalization [42].

The neuronal population expressing AgRP is restricted to the medial ARC and coexpresses NPY [43, 44]. AgRP and POMC neurons project to similar areas of the forebrain, but AgRP neurons do not send projections to the brainstem [45]. AgRP neurons also provide direct inhibitory input to POMC neurons via NPY receptors [36]. AgRP inhibits the basal activity of MC4Rs [46] and acts as a competitive antagonist that prevents binding of melanocortins. AgRP also regulates the type of $\mathrm{G}$ protein that is associated with the MC4R. While $\alpha-M S H$ stimulates increased coupling of the receptor with $\mathrm{G}_{\mathrm{s}} \alpha$, AgRP stimulates coupling of the receptor to the $\mathrm{G}_{\mathrm{i} / \mathrm{o}} \alpha$ subunit, which inhibits adenylate cyclase and reduces cellular cAMP levels [47].

The pathways described above permit melanocortins and their endogenous antagonist, AgRP, to influence multiple physiological processes, including control of blood pressure, serum glucose levels, energy expenditure, and food intake.

\section{Role in Food Intake}

It has been known for 30 years that melanocortins have a potent and long-lasting inhibitory effect on feeding [48]. However, optogenetics has revealed differences in how hypothalamic and hindbrain POMC populations suppress food intake. Acute activation of NTS POMC neurons produces an immediate inhibition of feeding behavior [49]. The NTS projects to the parabrachial nucleus (PBN) (Fig. 1a) $[50,51]$, which in turn projects to other areas that influence energy balance, including the lateral hypothalamic area (LHA), amygdala, VTA, and nucleus accumbens (NA) [52-54]. In contrast, arcuate POMC activation has delayed effects on feeding that require MC4Rs $[11,49,55]$. An important caveat is that optogenetic stimulation may not recapitulate more subtle, short-term actions of ARC POMC neurons on feeding initiation. Mandelblat-Cerf et al. [56] measured the electrophysiological activity of ARC POMC neurons in behaving animals; as described below, their results suggest that at least some POMC neurons may act on faster timescales to reduce the drive to seek food.

Interestingly, the drive to eat is generally stronger than systems promoting satiety. For instance, blocking MC4Rs has a more profound effect than stimulating them; the former causes a weight loss of $10-15 \%$ before ceasing to be effective, while the latter causes a weight gain of $25 \%$ in a similar amount of time and continues to cause hyperphagia as long as the antagonists are infused [57-60]. Thus, the primary purpose of the melanocortin system may be to prevent starvation rather than obesity.

Fasting excites AgRP neurons [61, 62], and both NPY and AgRP stimulate appetite and food-seeking behavior $[63,64]$. In recent years, novel techniques to manipulate and visualize AgRP neuronal activity have helped to advance our understanding of these neurons substantially. Photostimulation [11] or DREADD activation [10] of AgRP neurons, which are GABAergic, results in unopposed and immediate onset of hyperphagia. However, optetrode recording found that while the onset of feeding in fasted mice reduced firing rates of AgRP neurons, it did not abolish their activity; the firing rates remained elevated relative to those in mice without caloric deficiency following ad libitum night feeding [56]. This residual, persistent spiking may reflect a sustained drive to consume food, while additional circuits downstream of AgRP neurons prevent continued feeding.

AgRP gene deletion subtly reduces long-term weight gain, primarily by promoting thyroid hormone production [65]. Likewise, AgRP inhibits paraventricular TRH neurons via MC4Rs [66-68]. The mild hyperthyroidism in AgRP knockout mice, however, was not accompanied by altered spontaneous food intake [65, 69]. Furthermore, activating AgRP neurons can increase food intake independently of MCRs, suggesting that AgRP release is 


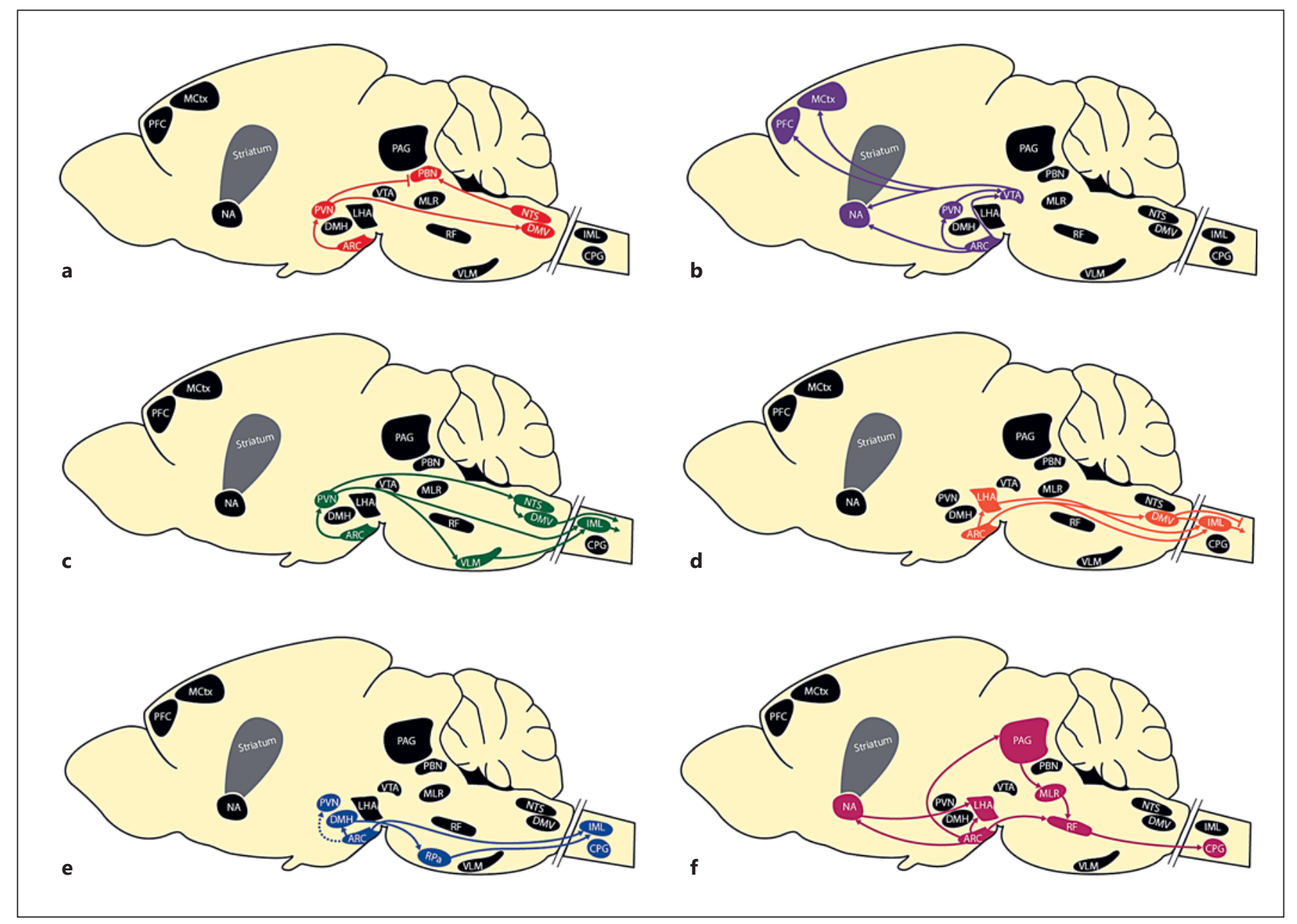

Fig. 1. Neuronal pathways whereby melanocortins alter energy balance. Melanocortin projections affect food intake (a), reward pathways (b), blood pressure (c), glucose homeostasis (d), basal energy expenditure (e), and locomotor activity (f). Primarily firstand second-order connections from proopiomelanocortin populations in the ARC and NTS are shown (see text for details). ARC, arcuate nucleus of the hypothalamus; CPG, central pattern generators; DMH, dorsomedial nucleus of the hypothalamus; DMV, dorsal motor nucleus of the vagus; IML, intermediolateral nucleus; LHA, lateral hypothalamic area; MCtx, motor cortex; MLR, mesencephalic locomotor region; NA, nucleus accumbens; NTS, nucleus of the solitary tract; $\mathrm{PAG}$, periaqueductal gray; $\mathrm{PBN}$, parabrachial nucleus; PFC, prefrontal cortex; PVN, paraventricular nucleus of the hypothalamus; RF, reticular formation; VLM, ventrolateral medulla; VTA, ventral tegmental area. not necessary for these effects [11]. These results imply that another product of AgRP neurons is important for appetite stimulation. Indeed, blocking PVH GABA or NPY receptors inhibits food intake following AgRP neuron activation [55]. Thus, it appears that AgRP neurons suppress the effects of POMC neurons through 3 mechanisms: they employ direct local GABAergic inhibition of POMC neurons and their PVH targets, AgRP-mediated antagonism at MCRs, and NPY receptor-mediated signaling to functionally counteract MCR signaling. The timescale of these mechanisms differs, however; GABA and NPY can each rapidly stimulate feeding, while a few hours are required for AgRP to stimulate feeding by blocking MC4Rs [70].

The ability of POMC and AgRP neurons to sense and respond to circulating markers of energy balance such as insulin, leptin, glucose, and ghrelin led to the hypothesis that the main role of these neurons is to match feeding to caloric needs [71]. Recent studies have confirmed that AgRP and POMC neuron activity in part reflects slow changes in energy balance that occur over the course of the day. Mandelblat-Cerf et al. [56] used optetrode elec- 
trophysiological recording in awake, behaving mice to measure absolute activity levels of identified AgRP neurons. Slow, opposite changes in AgRP and putative POMC neuron spiking were seen across hours, as the energy balance gradually changed.

An unexpected result from recent research on AgRP neuron activity is that not only do these neurons respond to internal cues signaling energy status, but they also respond within seconds to food consumption, the sight of food, or even to cues that predict food [72-74]. These timescales are inconsistent with a purely homeostatic role in feeding. Rather, these changes must reflect input from neurons that process information about the immediate availability and attractiveness of food in the environment. These fast changes may decrease the drive to continue the search for food, or they may predict meal consumption. Motivation and prediction of rewards are subserved in the brain by the mesocorticolimbic pathway; these results will therefore be discussed further in the next section.

Mc4r mutations cause the most common form of monogenic obesity in humans [75]. Mc3r mutations that reduce sensitivity to melanocortins appear to have been selected for in human populations facing frequent food scarcity [76]. Mc3r or Mc4r deficiency also results in hyperphagia and obesity in mice $[77,78]$. Identifying the key MCR-expressing neurons involved in appetite regulation has been a focus of intensive research recently. MC4Rexpressing neurons in the $\mathrm{PVH}$ are critical for regulating food intake; re-expression of MC4Rs on PVH SIM1-positive neurons in mice otherwise lacking MC4Rs abolishes hyperphagia and reduces their obesity [79-81]. $\operatorname{Sim} 1$ is expressed in most neurons of the PVH, some of which produce the neuroendocrine peptides oxytocin, arginine vasopressin, corticotropin-releasing hormone, TRH, and somatostatin. Studies using anatomical, pharmacogenetic, and optogenetic approaches suggest that PVH oxytocin neurons regulate acute feeding $[55,82,83]$. However, the importance of melanocortin-sensing oxytocin pathways to satiety is not yet settled $[81,84]$.

Until recently, it was believed that MC4R-expressing $\mathrm{PVH}$ neurons promote satiety by projecting to and activating neurons in the NTS $[85,86]$, increasing their sensitivity to gut-derived, afferent vagal satiety signals [87, 88]. However, channelrhodopsin-assisted circuit mapping has found that melanocortin-responsive $\mathrm{PVH}$ neurons target the preganglionic vagal motor neurons in the DMV and not the NTS (Fig. 1a) [81]. MC4Rs in the NTS may therefore respond to melanocortins produced locally to reduce food intake [89]. Instead, the PVH-DMV projection may modulate gut reflexes and gastric processes [90].

Shah et al. [81] found that the $\operatorname{Sim} 1$ neurons responsible for suppressing food intake synapse onto neurons expressing calcitonin gene-related protein (CGRP) in the $\mathrm{PBN}$, a key region for transmitting taste information to the cortex and forebrain regions such as the central nucleus of the amygdala that modulate perception and behavior [91, 92]. The lateral PBN has been implicated in taste [93, 94], learned taste aversion [95], and appetite suppression in response to illness or nausea [96-99]. Inhibiting CGRP neurons reduces nausea and increases food intake during illness but does not increase feeding under standard conditions $[55,100]$. The PBN satiety center is normally suppressed by GABAergic input from AgRP neurons (Fig. 1a) [99], permitting feeding when appropriate. However, when AgRP neurons are killed in adult mice, CGRP neurons become hyperactive and the mice cease to eat, resulting in starvation $[99,100]$. Inhibiting CGRP neurons in the PBN prevents this starvation $[99,100]$. Shah et al. [81] found that more than half of the PBN neurons receive input from glutamatergic PVH Sim 1 neurons. Furthermore, the majority of the PBNprojecting PVH neurons have MC4Rs.

These results were recently supported using optogenetic techniques. Using mice expressing Cre recombinase in MC4R neurons, Garfield et al. [101] found that optical activation and inhibition of PVH MC4R neurons exerted a bidirectional control of feeding via projections to the lateral PBN. These cells were found to mediate AgRP neuron-driven hunger. It is possible that this pathway allows melanocortins to induce appetite suppression by amplifying nausea or the discomfort of extreme fullness. However, mice showed a preference for activation of this circuit if they were calorically depleted. Given that fed mice showed neither an aversion to nor a preference for activation of this pathway [101], it is likely that the PVH MC4R to lateral PBN connection affects satiety in a manner unrelated to sensations of pleasure or pain.

\section{Actions in Reward Pathways}

The VTA contains the dopaminergic cell bodies of the mesocorticolimbic dopamine system, the reward circuitry of the brain. This limited number of dopamine neurons project widely, permitting coordinated responses to new rewarding stimuli (Fig. 1b). Dopamine influences the value placed on goals by acting in the orbital prefrontal cortex [102]. It also modulates memory consolidation 
in the amygdala and hippocampus $[103,104]$. In addition, dopamine encodes new motor programs that will facilitate obtaining a reward via the core region of the NA and dorsal striatum [105]. The dorsal striatum also plays a critical role in the anticipation and processing of aversive stimuli [106] and in altering future behavior following negative reinforcement [107], although these functions may not be primarily dopamine dependent $[108$, 109]. Finally, dopamine confers motivational salience or "wanting" to a reward (as opposed to the hedonic aspect or "liking" of a reward) by acting in the NA shell region $[110,111]$.

Melanocortins have the ability to alter dopaminergic reward pathways. MC4R signaling within dopamine-responsive neurons in the NA and dorsal striatum leads to morphological changes in dendritic spines that contribute to addictive behavior $[15,112]$. In addition, both POMC and AgRP neurons of the ARC project to the VTA $[113,114]$ and NA [45] (Fig. 1b). Indeed, $\alpha-\mathrm{MSH}$ stimulates dopamine release in the NA when microinjected into the VTA $[114,115]$. High levels of MC3R are found in the NA and VTA [24]. In addition, the MC3R - but not the MC4R - was recently reported to be expressed in up to a third of dopaminergic neurons of the VTA [116]. Recently, arcuate POMC neurons projecting to VTA dopaminergic neurons have been shown to modulate motivation for palatable food via MC3Rs [117]. Others have reported the MC4R is also present within the VTA [26, 118]. Within the VTA, AgRP neurons synapse on dopamine neurons [114]. Reduced activity of AgRP neurons facilitates VTA dopamine neuron activation of the NA [114]. Notably, the regulation of the VTA by AgRP neurons appears to be mediated by GABA rather than MCRs [114]. In addition, the PVH projects strongly to the VTA [119], potentially allowing second-order influences of melanocortins on that system. Thus, these effects in the VTA allow the melanocortin system to influence the overall level of dopamine released.

Glutamatergic projections from neurons in the prefrontal cortex and dopaminergic projections from the VTA enter the NA to synapse on medium spiny neurons (MSNs). These neurons express either the dopamine $\mathrm{D}_{1}$ or the dopamine $D_{2}$ receptor, which are $G_{s}$ and $G_{i}-$ coupled receptors, respectively. Dopamine released by stimuli diffuses into the synaptic cleft, where it excites $D_{1^{-}}$ expressing MSNs of the direct striatonigral pathway and inhibits $\mathrm{D}_{2}$-expressing MSNs of the indirect striatopallidal pathway, leading to activation of targeted motor cortical areas (Fig. 1b) [120, 121]. The emergence of genetic technologies to target discrete populations of neurons

The Role of the Melanocortin System in Metabolic Disease coupled with optogenetic and pharmacogenetic tools to manipulate their activity has provided a means for dissecting the contributions of these neuronal populations to various aspects of motivated behavior.

Dopamine neurons in the VTA exhibit 2 different patterns of dopamine release: (1) basal levels of dopamine release due to tonic firing, which activates high-affinity $\mathrm{D}_{2}$ receptors, and (2) bursts of elevated dopamine release due to phasic firing, which activates low-affinity $\mathrm{D}_{1}$ receptors [122-124]. These release patterns reflect 2 different functions of dopamine release. When animals encounter unexpected rewards, dopamine neurons evoke a burst of phasic firings that activates the low-affinity $\mathrm{D}_{1}$ receptor, which promotes new reward-directed learning $[125,126]$. Recent optogenetic studies have shown that the reinforcing properties of dopamine, cocaine, amphetamine, and natural rewards result from dopamine excitation of $D_{1}$ MSNs [127-130]. Increased activity of $D_{1}$ receptor MSNs may be a critical component of the longlasting neurological changes associated with drug sensitization and addiction [131].

The inhibition of the indirect pathway by the tonic firing of dopamine also increases motivation for reward and allows the activation of motor patterns necessary for its pursuit. Indeed, inhibition of $\mathrm{D}_{2}$ MSNs using a chemogenetic approach enhances the motivation to obtain cocaine [132]. In this way, dopamine release promotes reinforcement both by activating $\mathrm{D}_{1}$ MSNs and the direct pathway and by inhibiting $\mathrm{D}_{2}$ MSNs and the indirect pathway [129]. However, the absence of an expected reward suppresses dopamine neurons and relieves the $\mathrm{D}_{2}$ receptormediated inhibition of the indirect pathway. Optogenetic activation of $\mathrm{D}_{2}$ MSNs, normally inhibited by dopamine, reduces self-administration of cocaine [127, 132, 133], decreases initiation of movement and increases freezing, and causes mice to react as though they have received a punishment [134].

Until recently, the main role of melanocortin modulation of the mesocorticolimbic pathways was thought to be promoting preference for palatable and calorie-dense food. Like $\mathrm{D}_{1}$ receptor agonists, melanocortin agonists suppress food intake primarily through reduction in meal size, rather than meal frequency $[135,136]$. Loss of MC4R signaling in mice produces hyperphagia, but it is associated with decreased effortful pursuit of palatable food [137-139]. Activation of MC4Rs on $\mathrm{D}_{1}$ receptor MSNs decreases meal size, reinforces high-fat food preferences, and permits cocaine-induced anorexia [140, 141]. MC4R may also be expressed by $\mathrm{D}_{2}$ receptor neurons in the NA [140], which drive the striatopallidal pathway. MC4R-de- 
ficient mice decreased effortful responding to palatable food during restricted feeding, and this deficit was not rescued by re-expression of MC4R in $\mathrm{D}_{1}$ receptor MSNs [140]. Thus, MC4R signaling may influence the function of both the direct and the indirect reward pathways. While global deletion of the MC3R decreases preference for sucrose in female mice, the mean meal size is similar to that in wild types even when the difficulty in obtaining food is increased [116]. Together, these findings suggest that the rewarding aspects of food consumption are blunted by loss of MC4R but not MC3R signaling.

New work, however, suggests that POMC and AgRP neurons may play a more fundamental role in motivation for obtaining food. A nonhomeostatic aspect of the function of AgRP neurons had previously been suggested by observations of a decrease in AgRP neuron c-Fos expression $2 \mathrm{~h}$ after consumption of a calorie-free meal [74]. Recently, Chen et al. [73] used in vivo fiber photometry to monitor bulk changes in population calcium activity, pooled from many ARC AgRP neurons in awake, behaving mice. Whereas in fasted mice AgRP neuronal activity was elevated, their AgRP neuronal activity decreased within mere seconds as soon as eating began. Conversely, POMC activity, predictably low in hungry mice, rose almost immediately as feeding started; this rise did not prevent the mice from continuing to eat eagerly. They also found the presentation of food is sufficient to rapidly reverse the activation state of these neurons induced by an energy deficit. This rapid regulation is modulated by food palatability and occurs before any food is consumed [73]. Finally, if food was removed partway through the meal, the suppressed AgRP neurons again increased their activity, and the POMC neurons reduced their activity [72, 73]. Similar results were found using endoscopy to measure calcium activity in individual AgRP neurons in awake mice [72]. In addition, in vivo electrophysiological recording demonstrated that roughly half of responsive ARC neurons were modulated within minutes following food cue presentation only; AgRP neurons show a cueinduced decrease, while others (presumably POMC neurons) show a cue-induced increase [56].

These findings are reminiscent of classic experiments showing that dopamine release is a predictive signal of reward [142]. Electrophysiological recording of neurons in the VTA of monkeys found a spike of activity in response to an unexpected reward with fruit juice. When trained to associate the juice reward with a conditioned stimulus such as a tone, the spike of activity shifted to immediately following the tone. However, when the conditioned stimulus was given without the expected reward, the spike of activity was followed by a decrease in dopamine neuron firing below basal levels at the expected time of the reward. Thus, dopamine release encodes the expectation of a reward, and responds with a spike if the reward is better than expected and with a dip if it is worse [142]. Interestingly, dopamine is released by separate VTA neurons when unpleasant or aversive stimuli are encountered [143]. In humans, recent work suggests dopamine release reflects the confidence that a chosen behavior will lead to an expected outcome [144]. It therefore appears that dopamine release draws the individual's attention to surprising events, affecting the salience of objects and events. Potentially important stimuli seem more noticeable and more important, which assists decision-making. Note also that dopamine projections to the basal ganglia control motor patterns in response to these signals and projections to the cortex allow higher-order judgments about appropriate responses.

The parallels with the POMC and AgRP recording studies above are striking, including neuronal responsiveness to conditioned stimuli (the smell of food), modulation by the size of the reward (the palatability of food), and the generation of an error signal due to interruption of an anticipated reward (food removal). Further, there is evidence for a connection of AgRP and POMC neurons with motor pattern generators as well. The study by Mandelblat-Cerf et al. [56] demonstrated that in mice consuming liquid food, almost half of the ARC neurons were significantly modulated by individual licks or lick bouts. These changes in firing occurred approximately 1 $s$ before or after lick/bout onset, suggesting that these changes could help drive the initiation of upcoming licks. If rapid $\mathrm{POMC}$ and $\mathrm{AgRP}$ effects are indeed dependent on dopamine release, one would expect POMC neurons to promote a dopamine release or action in response to positive stimuli, while AgRP neurons would oppose these effects. In support of this concept, Betley et al. [72] found that mice avoid situations leading to activation of AgRP neurons, suggesting that AgRP activity contributes to negative reinforcement of behaviors leading to aversive outcomes. Likewise, strong AgRP neuronal inhibition conditioned the preference for flavors and places.

It is clear that the older view that AgRP neuronal activity produces hunger that directly causes eating was overly simplistic. In a recent review, Seeley and Berridge [145] assert that POMC and AgRP neurons are likely to modulate and receive input from the brain reward circuitry that reacts to food cues and mediates motivation to eat. In other words, elevated AgRP (and low POMC) may "prime 
the reactivity" of dopamine circuits to the sight, smell, and taste of food. In turn, the mesocorticolimbic circuitry must send feedback signals to the hypothalamus when food is encountered (or is unexpectedly absent), so that AgRP and POMC activity reflects the new incentive value of the food. Indeed, starvation signals generally increase mesocorticolimbic reactivity to food in both humans and rats [146-148]. Future experiments to test this and related models will require simultaneous manipulation of or recording from POMC/AgRP neurons and mesocorticolimbic pathways.

\section{Role in Blood Pressure}

The brainstem, especially the ventral medulla, has a key role in the maintenance of blood pressure. Sympathomedullary pathway activation is responsible for the stereotyped "fight-or-flight" response, which includes an increased heart rate and blood pressure, redirection of the blood flow away from digestive processes, and mobilization of stored energy. The NTS receives inhibitory baroreceptor afferents and serves a key role in stimulating inhibitory (blood pressure-lowering) pathways. Vasoconstriction and an increased heart rate and stroke volume are promoted by sympathetic output of the IML in the spinal cord. The limbic system, cerebral cortex, and hypothalamus directly or indirectly project to the IML to influence blood pressure (Fig. 1c). Activity of the IML is promoted by the rostral ventrolateral medulla, which in turn is tonically inhibited by GABAergic projections from the caudal ventrolateral medulla. NTS activation of the caudal ventrolateral medulla thus decreases blood pressure. A decreased heart rate/force is promoted by parasympathetic innervation from the DMV. The NTS promotes activity of the DMV, thus further decreasing blood pressure [149-151].

The melanocortin pathway has been implicated in obesity-related hypertension and increased sympathetic activity [58]. Unlike in high-fat diet-induced obese mice, blood pressure is not elevated in MC4R deficiency. Rather, rodents lacking MC4R often show reduced sympathetic nervous system (SNS) activity and blood pressure, even though they exhibit many other characteristics of the metabolic syndrome $[59,152,153]$. Compared with most obese patients, those deficient in MC4R show lower blood pressure and norepinephrine excretion even if they are very obese [154-156]. These observations have led to the hypothesis that obesity-related hypertension is MC4R dependent.

The Role of the Melanocortin System in Metabolic Disease
Preclinical and clinical studies have largely supported this idea. Chronic hypothalamic MCR activation can increase arterial pressure despite reduced food intake, whereas the inhibition of MCR significantly increases body weight without raising arterial pressure [57, 157]. Furthermore, acute central administration of $\alpha-\mathrm{MSH}$ increases the mean arterial pressure and heart rate in wildtype animals but not in MC4R knockout mice $[158,159]$. In normal animals, chronic MC4R antagonism slows the heart rate in a sustained manner and slightly reduces blood pressure despite hyperphagia and rapid weight gain $[59,160,161]$. MC4R antagonism can reduce blood pressure by $25-30 \mathrm{~mm} \mathrm{Hg}$ in lean, spontaneously hypertensive rats, which are known to have increased SNS activity [59]. Correspondingly, an MC4R agonist increased systolic and diastolic blood pressure in obese volunteers [157]. These findings indicate that for excess weight gain to increase SNS activity and elevate blood pressure, MC4R activation is necessary.

Leptin links obesity, SNS overactivity, and high blood pressure. Elevating leptin levels of lean rodents to those seen in rodents with severe obesity causes chronic increases in blood pressure, secondary to adrenergic activity [162]. These chronic effects of hyperleptinemia on SNS activity and blood pressure regulation require an intact POMC neuron-MC4R axis; the ability of leptin to raise blood pressure requires both leptin receptors and MC4R in POMC neurons [152, 163, 164]. Recent work suggests that IRS2 signaling in POMC neurons is essential for the chronic actions of leptin to raise mean arterial pressure [165].

The PVH represents an important location for the convergence of neuronal inputs that control sympathetic outflow and cardiovascular activity through its projections to the rostral ventrolateral medulla and the intermediolateral column of the spinal cord (Fig. 1c) [166]. The $\mathrm{PVH}$ is also involved in prolonged excessive sympathetic activation; injection of an MCR agonist into the PVH of male rats increased renal sympathetic afferent activity and mean arterial pressure. These effects were attenuated but not blocked by AgRP or a selective MC4R antagonist, indicating that activation of both MC3Rs and MC4Rs in the PVH can increase sympathetic outflow and blood pressure [167]. Thus, MC3Rs in the PVH may exert a tonic excitatory effect on sympathetic activity.

Second-order melanocortin-responsive neurons are also located in the hindbrain. Some studies have found a reduced blood pressure and heart rate following microinjection of $\alpha-\mathrm{MSH}$ or a synthetic agonist into the NTS of anesthetized, spontaneously hypertensive rats and nor-

Neuroendocrinology 2017;104:330-346 337 
motensive Sprague-Dawley rats $[168,169]$. On the other hand, an $\alpha-M S H$-expressing viral vector injected into the NTS increased sympathetic activity and the heart rate and reduced parasympathetic activity in mice [170]. Similarly, Iwasa et al. [171] observed an increased heart rate after a-MSH had been microinjected into the IML, the location of cholinergic sympathetic preganglionic neurons. Recent work shows that re-expressing MC4Rs specifically in cholinergic neurons renders MC4R null mice hypertensive without affecting their obesity [32]. These studies support the hypothesis that MC4Rs in sympathetic preganglionic neurons of the IML play an important role in obesity-associated hypertension.

\section{Role in Glucose Control}

Along with its role in the regulation of blood pressure, the melanocortin system influences glucose homeostasis and, in particular, insulin secretion, glucose utilization, and glucose production. Intracerebroventricular administration of an MCR or MC4R agonist reduces plasma insulin levels in leptin-deficient and lean mice and improves hepatic and skeletal insulin sensitivity [172-174]. Conversely, chronic intracerebroventricular administration of an MCR antagonist impairs hepatic and skeletal muscle insulin sensitivity regardless of the body weight [174]. Mutations in the human MC4R gene may lead to hyperinsulinemia when compared to obese control subjects [174], although the evidence is inconsistent [175]. Nevertheless, MC4Rs appear likely to influence the maintenance of normal glucose homeostasis. Additional studies are needed to examine the real-time effect on glucose homeostasis of activating or suppressing hypothalamic and hindbrain POMC neurons.

Recently there has been great interest in the downstream targets of POMC neurons that are responsible for the glucose-regulating actions of POMC neurons. Importantly, restoring MC4Rs in the PVH does not rescue from hyperglycemia or hyperinsulinemia; therefore, the PVH does not mediate actions of melanocortin on glucose homeostasis [79]. Rather, it appears that the activity of MC4Rs in brainstem autonomic regions prevents hyperglycemia and hyperinsulinemia. Recent studies evaluated 2 mouse models with MC4R expression restored specifically in just cholinergic DMV preganglionic parasympathetic neurons or in both cholinergic DMV preganglionic parasympathetic and IML sympathetic neurons. Reactivation of MC4R signaling in all cholinergic neurons ameliorated both hyperglycemia and hyperinsulinemia
[176]. By comparison, reactivation of MC4Rs in parasympathetic afferent neurons located in the nodose ganglia did not prevent hyperglycemia but did abolish hyperinsulinemia [176]. This finding suggests a role for the SNS in regulating insulin secretion; MC4Rs in the DMV may inhibit spontaneously active parasympathetic preganglionic neurons that stimulate insulin secretion (Fig. 1d) $[176,177]$. Glucose intolerance was seen in both groups, suggesting insulin resistance [178]. Thus, these data suggest that MC4Rs expressed in preganglionic sympathetic neurons of the IML may mediate the ability of melanocortins to suppress blood glucose levels. It remains unknown whether NTS or ARC POMC neurons are the source of the endogenous ligand for the hindbrain MC4R. Interestingly, under hypoglycemic conditions, $100 \%$ of NTS neurons were found to depolarize in response to a-MSH, as opposed to $35 \%$ under normoglycemic conditions [179].

Leptin can have a profound effect on glucose homeostasis via the melanocortin system - for example, by increasing hepatic gluconeogenesis and by decreasing glycogenolysis [180]. Central blockade of MCRs in streptozotocin-induced diabetic rats blocked a leptin-mediated decrease in blood glucose [181]. These effects may be due to leptin's actions on POMC neurons, since mice lacking the leptin receptor (OBR) selectively in POMC neurons have strain-dependent glucose intolerance [182, 183]. Conversely, OBR reactivation in POMC neurons in OBR null mice normalized hepatic glucose production at a time point when their body weight was similar to that of whole-body $d b$ (leptin receptor null) mice $[184,185]$, indicating that POMC neuron OBRs can regulate glucose homeostasis independently of body weight. However, $d b$ mice produce very high levels of leptin [186, 187]; thus, activated POMC OBRs may reverse hyperglycemia only in response to abnormally strong signaling. Lower leptin levels could still inhibit the release of AgRP from AgRP neurons without greatly increasing the $\alpha$-MSH release from POMC neurons. Indeed, a recent study provides strong evidence that AgRP neurons may have a dominant effect on glucose regulation by controlling glucagon production. In $o b$ mice (which cannot produce leptin), deletion of leptin receptors from AgRP neurons, but not from POMC neurons, prevented the ability of low doses of leptin to correct hyperglycemia. Further, AgRP action on MCRs, but not NPY or GABA release by these neurons, mediated this effect [187]. Thus, although both AgRP and POMC neurons are involved in leptin's glucose-lowering actions in diabetic states, only AgRP neurons are required for these actions. 
Melanocortin signaling in the LHA has recently been shown to regulate glucose tolerance and sympathetic nerve activity. Restoring expression of MC4Rs specifically in the LHA improves glucose intolerance in obese MC4R null mice without affecting body weight. This effect results from increased sympathetic nerve activity leading to increased uptake of Glut4 expression and glucose uptake by interscapular brown adipose tissue (BAT) (Fig. 1d) [188].

\section{Role in Energy Expenditure}

The melanocortin system also influences caloric expenditure. Several mechanisms involving heat generation, cellular metabolism, and locomotor activity have the potential to underlie this effect. The MC4Rs in the PVH do not mediate melanocortin's actions on energy expenditure [79]. Rather, these functions involve melanocortin-responsive autonomic neurons [189].

Melanocortins appear to induce a dual effect on body temperature; a well-studied, prolonged induction of hyperthermia follows a newly identified, rapid reduction in body temperature. The latter seems to be independent of MC4Rs and possibly dependent on a similar biphasic effect on heart rate $[190,191]$. BAT plays a crucial role in adaptive thermogenesis in response to diet or environmental challenges. Chemogenetic stimulation of POMC neurons or their exposure to insulin and leptin promotes the conversion of white adipose tissue into BAT via sympathetic activation [192]. Melanocortins also modulate sympathetic outflow to affect BAT metabolism in order to promote energy expenditure [193]. Conversely, when administered to the dorsomedial nucleus of the hypothalamus, AgRP blunts the thermogenic effect of melanotan II [194]. ARC POMC neurons project directly to the IML, where they activate sympathetic preganglionic fiber cell bodies (Fig. 1e) [18, 32]. The IML in turn projects to postganglionic neurons innervating BAT [195-197]. Indeed, MC4Rs in sympathetic preganglionic neurons are required to regulate energy expenditure, including heat generation in response to excess caloric intake or cold exposure and conversion of white adipose tissue into thermogenic fat [178].

Another mechanism for controlling energy expenditure is modulating cellular energy use through the hypothalamic-pituitary-thyroid axis. Thyroid hormone signaling acts in concert with SNS stimulation to promote adaptive thermogenesis in BAT and to affect other tissues including white adipose tissue and skeletal muscle [198].
In general, hypothalamic melanocortins are believed to stimulate the thyroid axis, while AgRP inhibits it. As previously mentioned, AgRP null mice exhibit increased circulating thyroid hormone levels, leading to an increased metabolic rate and body temperature [65]. While $\alpha-\mathrm{MSH}$ has the ability to increase thyrotropin production when infused intracerebroventricularly [199-201], MC4R mutations in humans have no impact on free thyroxin levels, although a tendency in some patients to paradoxically have higher thyrotropin levels has been observed [202].

$\mathrm{MC} 4 \mathrm{R}$ is not required for the fasting-induced suppression of the central axis [203]. Interestingly, MC4R signaling regulates hepatic thyroid hormone metabolism during fasting - although whether this effect is direct or mediated by the CNS is not known [203]. Thus, melanocortin signaling indirectly lowers thyroid hormone levels and the metabolic rate during fasting by accelerating $\mathrm{T}_{4}$ clearance.

The extent to which caloric expenditure through locomotor activity contributes to body weight in rodents is debated [204, 205]. In general, locomotion is initiated by the mesencephalic locomotor region (MLR) and its projections to the medial reticular formation (RF) in the lower brainstem (Fig. 1f). Signals relayed from the RF to the locomotor central pattern generator in the spinal cord trigger locomotor patterns. The MLR receives inputs from the thalamus and the basal ganglia. The latter select desired movements and influence voluntary exercise such as exploratory, spontaneous, conditioned, and druginduced locomotor activity $[206,207]$. The motor cortex in the forebrain can also drive locomotion via reciprocal connections with the thalamus and basal ganglia. It may also bypass these structures and communicate directly with the locomotor central pattern generator [208]. In addition, the ARC projects to the MLR via the periaqueductal gray and may also project directly to the RF and indirectly to the RF via the LHA or NA [141, 209].

Locomotor activity can involve pursuit of food when calories are needed or pursuit of nonnutritive activities during times of energy surplus. Decreased circulating levels of leptin, as would be seen during a famine, reduce general locomotor activity while increasing food-seeking/anticipatory behavior [210]. Indeed, leptin increases general locomotor activity, and this action requires arcuate neuronal targets $[210,211]$. Evidence suggests an altered melanocortin release is involved in this effect. Deletion of leptin receptors on POMC neurons reduces locomotor activity [182]. In addition, restoring leptin receptors only in POMC neurons in $d b$ mice normalizes locomotor activity but not body weight [185]. Further- 
more, locomotor activity of young, nonobese, but hyperleptinemic MC4R null males is significantly lower than that of wild-type males [212]. Therefore, melanocortin signaling via MC4Rs may underlie leptin's ability to promote general locomotor activity. In contrast, MC3R signaling may promote food anticipatory activity in a leptinindependent manner; MC3r null mice exhibit decreased food-anticipatory activity [213], but deleting MC3Rs in $o b$ mice does not change their elevated food-seeking behavior.

Dietrich et al. [214] recently used a chemogenetic approach to demonstrate that activation of AgRP neurons in the absence of food triggers foraging and repetitive behaviors, which are reverted by food consumption. These stereotypic behaviors are coupled with an increased willingness to explore normally fear- or anxiety-provoking environments. These effects are most likely not due to altered melanocortin signaling, since NPY 5 receptor signaling is necessary to mediate the repetitive behaviors after AgRP neuron activation [214]. As previously described, inhibiting AgRP activity provides a way to rapidly halt the energy-intensive activity of foraging when food is found [73].

\section{Conclusions}

The breadth of the physiological roles served by the melanocortin system is often overlooked. As we have described, this system controls many aspects of metabolism that can contribute to obesity and its comorbidities. Indeed, the metabolic syndrome may have a dysfunction of the melanocortin system at its core.

The ability of melanocortins to suppress feeding and increase energy expenditure has made MCRs the focus of the search for an antiobesity treatment [215]. In addition, the work described above showing that the melanocortin system influences circulating glucose levels has generated great interest in it as a potential target for treatment of obesity-related type 2 diabetes [216]. Not surprisingly, MCR-targeted drugs have been plagued by problematic side effects, including undesirable increases in SNS activity, heart rate, and blood pressure [158, 217]. Again, these outcomes are not off-target effects, but rather main physiological functions of melanocortins. These problems have thus far prevented the use of antiobesity drugs that target the activation of MC4R in the clinic [154, 218].

Recent work suggests one possible approach for circumnavigating this roadblock. MCRs are generally coupled to $G_{s} \alpha$ proteins that increase intracellular cAMP and activate protein kinase $A . G_{s} \alpha$ does not mediate all of the actions of MC4R, however [219]. Recent studies also suggest that melanocortins act through $\mathrm{G}_{\mathrm{q} / 11} \alpha$ pathways in the PVH to regulate food intake, linear growth, cholesterol metabolism, and Crh gene expression [220]. If, as suggested by these studies [220,221], heart rate and blood pressure are mediated by $\mathrm{G}_{\mathrm{s}} \alpha, \mathrm{a} \mathrm{G}_{\mathrm{q} / 11} \alpha$-biased MC4R agonists may be a potential treatment for obesity.

If this approach fails, a clearer picture of the precise neural circuits that mediate each of the actions of melanocortins may provide solutions. As we have seen, the evidence to date suggests that downstream melanocortinresponsive pathways do diverge and may be separable in animal models by using technologies to target specific second-order neuronal populations that express unique neuropeptides or other markers. Targeting pharmacological strategies to particular MCR-expressing circuits in humans, however, is much more challenging. Ultimately, the development of drugs free of unwanted side effects may require identifying other targets in second- or thirdorder neurons rather than MCRs themselves.

The ongoing effort to understand the function of these circuits forms part of the larger push within neuroscience to develop a more integrated view of circuit activity. Unraveling the complexity of neural communication in real time is a massive task. Technical advances in being able to manipulate neuronal activity in awake, behaving animals as well as new approaches to monitoring and interpreting neuronal activity as it occurs offer tremendous benefits. However, the need for neuroanatomy assisted by well-designed neural tracers, traditional electrophysiology, and purely genetic approaches will remain. Ultimately, a more complete understanding of melanocortin pathways and their myriad functions will allow treatments tailored to the mix of metabolic disorders in the individual patient.

\section{References}

1 Ogden CL, Carroll MD, Kit BK, Flegal KM: Prevalence of childhood and adult obesity in the United States, 2011-2012. JAMA 2014; 311:806-814

2 Flegal KM, Carroll MD, Kit BK, Ogden CL: Prevalence of obesity and trends in the distribution of body mass index among US adults, 1999-2010. JAMA 2012;307:491-497.

3 Nguyen NT, Magno CP, Lane KT, Hinojosa MW, Lane JS: Association of hypertension, diabetes, dyslipidemia, and metabolic syndrome with obesity: findings from the $\mathrm{Na}$ tional Health and Nutrition Examination Survey, 1999 to 2004. J Am Coll Surg 2008; 207:928-934. 
4 Dixon JB, Dixon ME, O’Brien PE: Depression in association with severe obesity - changes with weight loss. Arch Intern Med 2003;163: 2058-2065.

5 Flegal KM, Kit BK, Orpana H, Graubard BI: Association of all-cause mortality with overweight and obesity using standard body mass index categories: a systematic review and meta-analysis. JAMA 2013;309:71-82.

6 Flegal KM, Graubard BI, Williamson DF, Gail MH: Excess deaths associated with underweight, overweight, and obesity. JAMA 2005; 293:1861-1867.

7 Mokdad AH, Marks JS, Stroup DF, Gerberding JL: Correction: actual causes of death in the United States, 2000. JAMA 2005;293:293294.

8 Tartaglia LA, Dembski M, Weng X, Deng N, Culpepper J, Devos R, Richards GJ, Campfield LA, Clark FT, Deeds J, Muir C, Sanker S, Moriarty A, Moore KJ, Smutko JS, Mays GG, Wool EA, Monroe CA, Tepper RI: Identification and expression cloning of a leptin receptor, OB-R. Cell 1995;83:1263-1271.

9 Halaas JL, Gajiwala KS, Maffei M, Cohen SL, Chait BT, Rabinowitz D, Lallone RL, Burley SK, Friedman JM: Weight-reducing effects of the plasma protein encoded by the obese gene. Science 1995;269:543-546.

10 Krashes MJ, Koda S, Ye CP, Rogan SC, Adarns AC, Cusher DS, Maratos-Flier E, Roth BL, Lowell BB: Rapid, reversible activation of AgRP neurons drives feeding behavior in mice. J Clin Invest 2011;121:1424-1428.

11 Aponte Y, Atasoy D, Sternson SM: AGRP neurons are sufficient to orchestrate feeding behavior rapidly and without training. Nat Neurosci 2011;14:351-355.

12 Zhang F, Gradinaru V, Adamantidis AR, Durand R, Airan RD, de Lecea L, Deisseroth K: Optogenetic interrogation of neural circuits: technology for probing mammalian brain structures. Nat Protoc 2010;5:439-456.

13 Cohen MX, Bour L, Mantione M, Figee M, Vink M, Tijssen MAJ, van Rootselaar A-F, van den Munckhof P, Schuurman PR, Denys $\mathrm{D}$ : Top-down-directed synchrony from medial frontal cortex to nucleus accumbens during reward anticipation. Hum Brain Mapp 2012;33:246-252.

14 Cone RD: Anatomy and regulation of the central melanocortin system. Nat Neurosci 2005; 8:571-578.

15 Niikura K, Zhou Y, Ho A, Kreek MJ: Proopiomelanocortin (POMC) expression and conditioned place aversion during protracted withdrawal from chronic intermittent escalatingdose heroin in POMC-EGFP promoter transgenic mice. Neuroscience 2013;236:220 232.

16 Civelli O, Birnberg N, Herbert E: Detection and quantitation of pro-opiomelanocortin mRNA in pituitary and brain tissues from different species. J Biol Chem 1982;257:67836787.
17 Grauerholz BL, Jacobson JD, Handler MS, Millington WR: Detection of pro-opiomelanocortin mRNA in human and rat caudal medulla by RT-PCR. Peptides 1998;19:939-948.

18 Elias CF, Lee C, Kelly J, Aschkenasi C, Ahima RS, Couceyro PR, Kuhar MJ, Saper CB, Elmquist JK: Leptin activates hypothalamic CART neurons projecting to the spinal cord. Neuron 1998;21:1375-1385.

19 Hentges ST, Nishiyama M, Overstreet LS, Stenzel-Poore M, Williams JT, Low MJ: GABA release from proopiomelanocortin neurons. J Neurosci 2004;24:1578-1583.

20 Hentges ST, Otero-Corchon V, Pennock RL, King CM, Low MJ: Proopiomelanocortin expression in both GABA and glutamate neurons. J Neurosci 2009;29:13684-13690.

21 Burke LK, Doslikova B, D'Agostino G, Greenwald-Yarnell M, Georgescu T, Chianese R, Martínez de Morentin PB, Ogunnowo-Bada E, Cansell C, Valencia-Torres L, Garfield AS, Apergis-Schoute J, Lam DD, Speakman JR, Rubinstein M, Low MJ, Rochford JJ, Myers MG, Evans ML, Heisler LK: Sex difference in physical activity, energy expenditure and obesity driven by a subpopulation of hypothalamic POMC neurons. Mol Metab 2016;5: 245-252.

22 Lam DD, Attard CA, Mercer AJ, Myers MG Jr, Rubinstein M, Low MJ: Conditional expression of Pomc in the Lepr-positive subpopulation of POMC neurons is sufficient for normal energy homeostasis and metabolism. Endocrinology 2015;156:1292-1302.

23 Dennison CS, King CM, Dicken MS, Hentges ST: Age-dependent changes in amino acid phenotype and the role of glutamate release from hypothalamic proopiomelanocortin neurons. J Comp Neurol 2016;524:12221235.

24 Roselli-Rehfuss L, Mountjoy KG, Robbins LS, Mortrud MT, Low MJ, Tatro JB, Entwistle ML, Simerly RB, Cone RD: Identification of a receptor for gamma melanotropin and other proopiomelanocortin peptides in the hypothalamus and limbic system. Proc Natl Acad Sci USA 1993;90:8856-8860.

25 Mountjoy KG, Mortrud MT, Low MJ, Simerly RB, Cone RD: Localization of the melanocortin-4 receptor (MC4-R) in neuroendocrine and autonomic control circuits in the brain. Mol Endocrinol 1994;8:1298-1308.

26 Mountjoy KG: Distribution and function of melanocortin receptors within the brain. Adv Exp Med Biol 2010;681:29-48.

27 Kishi T, Aschkenasi CJ, Lee CE, Mountjoy KG, Saper CB, Elmquist JK: Expression of melanocortin 4 receptor mRNA in the central nervous system of the rat. J Comp Neurol 2003;457:213-235

28 Liu HY, Kishi T, Roseberry AG, Cai XL, Lee CE, Montez JM, Friedman JM, Elmquist JK: Transgenic mice expressing green fluorescent protein under the control of the melanocortin-4 receptor promoter. J Neurosci 2003;23: $7143-7154$.
29 Lu XY, Barsh GS, Akil H, Watson SJ: Interaction between $\alpha$-melanocyte-stimulating hormone and corticotropin-releasing hormone in the regulation of feeding and hypothalamo-pituitary-adrenal responses. J Neurosci 2003;23:7863-7872.

30 Zhou L, Sutton GM, Rochford JJ, Semple RK, Lam DD, Oksanen LJ, Thornton-Jones ZD, Clifton PG, Yueh CY, Evans ML, McCrimmon RJ, Elmquist JK, Butler AA, Heisler LK: Serotonin $2 \mathrm{C}$ receptor agonists improve type 2 diabetes via melanocortin-4 receptor signaling pathways. Cell Metab 2007;6:398-405.

31 Li SY, Chen YL, Zeng JY, Xie WQ, Kang ZM: Melanocortin-4 receptor expression in autonomic circuitry involved in gastric function. Int J Clin Exp Med 2015;8:4152-4157.

32 Sohn JW, Harris LE, Berglund ED, Liu T, Vong L, Lowell BB, Balthasar N, Williams KW, Elmquist JK: Melanocortin 4 receptors reciprocally regulate sympathetic and parasympathetic preganglionic neurons. Cell 2013;152:612-619.

33 Jegou S, Boutelet I, Vaudry H: Melanocortin-3 receptor mRNA expression in pro-opiomelanocortin neurones of the rat arcuate nucleus. J Neuroendocrinol 2000;12:501-505.

34 Mounien L, Bizet P, Boutelet I, Vaudry H, Jégou S: Expression of melanocortin MC3 and MC4 receptor mRNAs by neuropeptide Y neurons in the rat arcuate nucleus. Neuroendocrinology 2005;82:164-170.

35 Renquist BJ, Lippert RN, Sebag JA, Ellacott KLJ, Cone RD: Physiological roles of the melanocortin MC3 receptor. Eur J Pharmacol 2011;660:13-20.

36 Cowley MA, Smart JL, Rubinstein M, Cordan MG, Diano S, Horvath TL, Cone RD, Low MJ: Leptin activates anorexigenic POMC neurons through a neural network in the arcuate nucleus. Nature 2001;411:480-484.

37 Srinivasan S, Lubrano-Berthelier C, Govaerts C, Picard F, Santiago P, Conklin BR, Vaisse C: Constitutive activity of the melanocortin-4 receptor is maintained by its $\mathrm{N}$-terminal domain and plays a role in energy homeostasis in humans. J Clin Invest 2004;114:1158-1164.

38 Grueter BA, Rothwell PE, Malenka RC: Integrating synaptic plasticity and striatal circuit function in addiction. Curr Opin Neurobiol 2012;22:545-551.

39 Andrade R: Electrophysiological properties of $\mathrm{Ga}_{\mathrm{s}}$-coupled 5-HT receptors (5-HT4, 5-HT6, 5-HT7); in Roth B (ed): The Serotonin Receptors: From Molecular Pharmacology to $\mathrm{Hu}-$ man Therapeutics. Totowa, Humana Press, 2006, pp 481-494.

40 Cowley MA, Pronchuk N, Fan W, Dinulescu DM, Colmers WF, Cone RD: Integration of NPY, AGRP, and melanocortin signals in the hypothalamic paraventricular nucleus: evidence of a cellular basis for the adipostat. Neuron 1999;24:155-163. 
41 Caruso V, Lagerström MC, Olszewski PK, Fredriksson R, Schiöth HB: Synaptic changes induced by melanocortin signalling. Nat Rev Neurosci 2014;15:98-110.

42 Shinyama H, Masuzaki H, Fang H, Flier JS: Regulation of melanocortin-4 receptor signaling: agonist-mediated desensitization and internalization. Endocrinology 2003; 144: 1301-1314.

43 Broberger C, Johansen J, Johansson C, Schalling M, Hökfelt T: The neuropeptide Y agouti gene-related protein (AGRP) brain circuitry in normal, anorectic, and monosodium glutamate-treated mice. Proc Natl Acad Sci USA 1998:95:15043-15048.

44 Hahn TM, Breininger JF, Baskin DG, Schwartz MW: Coexpression of Agrp and NPY in fasting-activated hypothalamic neurons. Nat Neurosci 1998;1:271-272.

45 Bagnol D, Lu XY, Kaelin CB, Day HEW, Ollmann M, Gantz I, Akil H, Barsh GS, Watson SJ: Anatomy of an endogenous antagonist: relationship between agouti-related protein and proopiomelanocortin in brain. J Neurosci 1999; 19:RC26.

46 Haskell-Luevano C, Monck EK: Agouti-related protein functions as an inverse agonist at a constitutively active brain melanocortin-4 receptor. Regul Pept 2001;99:1-7.

47 Büch TR, Heling D, Damm E, Gudermann T, Breit A: Pertussis toxin-sensitive signaling of melanocortin-4 receptors in hypothalamic GT1-7 cells defines agouti-related protein as a biased agonist. J Biol Chem 2009;284: 26411-26420.

48 Poggioli R, Vergoni AV, Bertolini A: ACTH(1-24) and $\alpha$-MSH antagonize feeding behavior stimulated by kappa opiate agonists. Peptides 1986;7:843-848.

49 Zhan C, Zhou J, Feng Q, Zhang JE, Lin S, Bao $\mathrm{J}, \mathrm{Wu}$ P, Luo M: Acute and long-term suppression of feeding behavior by POMC neurons in the brainstem and hypothalamus, respectively. J Neurosci 2013;33:3624-3632.

50 Cho YK, Li C-S, Smith DV: Gustatory projections from the nucleus of the solitary tract to the parabrachial nuclei in the hamster. Chem Senses 2002;27:81-90.

51 Alhadeff AL, Rupprecht LE, Hayes MR: GLP1 neurons in the nucleus of the solitary tract project directly to the ventral tegmental area and nucleus accumbens to control for food intake. Endocrinology 2012;153:647-658.

52 Miller RL, Stein MK, Loewy AD: Serotonergic inputs to FoxP2 neurons of the pre-locus coeruleus and parabrachial nuclei that project to the ventral tegmental area. Neuroscience 2011;193:229-240.

53 Blessing WW: The Lower Brainstem and Bodily Homeostasis. New York, Oxford University Press, 1997.

54 Li CS, Chung S, Lu DP, Cho YK: Descending projections from the nucleus accumbens shell suppress activity of taste-responsive neurons in the hamster parabrachial nuclei. J Neurophysiol 2012;108:1288-1298.
55 Atasoy D, Betley JN, Su HH, Sternson SM: Deconstruction of a neural circuit for hunger. Nature 2012;488:172-177.

56 Mandelblat-Cerf Y, Ramesh RN, Burgess CR, Patella P, Yang ZF, Lowell BB, Andermann ML: Arcuate hypothalamic AgRP and putative POMC neurons show opposite changes in spiking across multiple timescales. Elife 2015;4:e07122.

57 Kuo JJ, Silva AA, Hall JE: Hypothalamic melanocortin receptors and chronic regulation of arterial pressure and renal function. Hypertension 2003;41(pt 2):768-774.

58 Kuo JJ, da Silva AA, Tallam LS, Hall JE: Role of adrenergic activity in pressor responses to chronic melanocortin receptor activation. Hypertension 2004;43:370-375.

59 da Silva AA, do Carmo JM, Kanyicska B, Dubinion J, Brandon E, Hall JE: Endogenous melanocortin system activity contributes to the elevated arterial pressure in spontaneously hypertensive rats. Hypertension 2008;51: 884-890.

60 Tallam LS, Kuo JJ, da Silva AA, Hall JE: Cardiovascular, renal, and metabolic responses to chronic central administration of agoutirelated peptide. Hypertension 2004;44:853858.

61 Yang Y, Atasoy D, Su HH, Sternson SM: Hunger states switch a flip-flop memory circuit via a synaptic AMPK-dependent positive feedback loop. Cell 2011;146:992-1003.

62 Liu T, Kong D, Shah BP, Ye C, Koda S, Saunders A, Ding JB, Yang Z, Sabatini BL, Lowell BB: Fasting activation of AgRP neurons requires NMDA receptors and involves spinogenesis and increased excitatory tone. Neuron 2012;73:511-522

63 Clark JT, Kalra PS, Crowley WR, Kalra SP: Neuropeptide $\mathrm{Y}$ and human pancreatic polypeptide stimulate feeding behavior in rats. Endocrinology 1984;115:427-429.

64 Ollmann MM, Wilson BD, Yang YK, Kerns JA, Chen Y, Gantz I, Barsh GS: Antagonism of central melanocortin receptors in vitro and in vivo by agouti-related protein. Science 1997:278:135-138.

65 Wortley KE, Anderson KD, Yasenchak J, Murphy A, Valenzuela D, Diano S, Yancopoulos GD, Wiegand SJ, Sleeman MW: Agouti-related protein-deficient mice display an age-related lean phenotype. Cell Metab 2005; 2:421-427.

66 Diano S, Naftolin F, Goglia F, Horvath TL: Segregation of the intra- and extrahypothalamic neuropeptide $\mathrm{Y}$ and catecholaminergic inputs on paraventricular neurons, including those producing thyrotropin-releasing hormone. Regul Pept 1998;75-76:117-126.

67 Fekete C, Sarkar S, Rand WM, Harney JW, Emerson CH, Bianco AC, Lechan RM: Agouti-related protein (AGRP) has a central inhibitory action on the hypothalamic-pituitarythyroid (HPT) axis; comparisons between the effect of AGRP and neuropeptide $Y$ on energy homeostasis and the HPT axis. Endocrinology 2002;143:3846-3853.
68 Fekete C, Marks DL, Sarkar S, Emerson CH, Rand WM, Cone RD, Lechan RM: Effect of agouti-related protein in regulation of the hypothalamic-pituitary-thyroid axis in the melanocortin 4 receptor knockout mouse. Endocrinology 2004;145:4816-4821.

69 Luquet S, Perez FA, Hnasko TS, Palmiter RD: NPY/AgRP neurons are essential for feeding in adult mice but can be ablated in neonates. Science 2005;310:683-685.

70 Krashes MJ, Shah BP, Koda S, Lowell BB: Rapid versus delayed stimulation of feeding by the endogenously released AgRP neuron mediators GABA, NPY, and AgRP. Cell Metab 2013;18:588-595.

71 Cone RD, Cowley MA, Butler AA, Fan W, Marks DL, Low MJ: The arcuate nucleus as a conduit for diverse signals relevant to energy homeostasis. Int J Obes Relat Metab Disord 2001;25(suppl 5):S63-S67.

72 Betley JN, Xu S, Cao ZF, Gong R, Magnus CJ, Yu Y, Sternson SM: Neurons for hunger and thirst transmit a negative-valence teaching signal. Nature 2015;521:180-185.

73 Chen Y, Lin YC, Kuo TW, Knight ZA: Sensory detection of food rapidly modulates arcuate feeding circuits. Cell 2015;160:829-841.

74 Becskei C, Lutz TA, Riediger T: Diet-derived nutrients mediate the inhibition of hypothalamic NPY neurons in the arcuate nucleus of mice during refeeding. Am J Physiol Regul Integr Comp Physiol 2009;297:R100-R110.

75 Ramachandrappa S, Farooqi IS: Genetic approaches to understanding human obesity. J Clin Invest 2011;121:2080-2086.

76 Yoshiuchi I: Evidence for natural selection at the melanocortin-3 receptor gene in European and African populations. Acta Diabetol 2016;53:583-587.

77 Butler AA, Kesterson RA, Khong K, Cullen MJ, Pelleymounter MA, Dekoning J, Baetscher M, Cone RD: A unique metabolic syndrome causes obesity in the melanocortin-3 receptor-deficient mouse. Endocrinology 2000;141:3518-3521.

78 Sutton GM, Trevaskis JL, Hulver MW, McMillan RP, Markward NJ, Babin MJ, Meyer EA, Butler AA: Diet-genotype interactions in the development of the obese, insulin-resistant phenotype of C57BL/6J mice lacking melanocortin-3 or -4 receptors. Endocrinology 2006;147:2183-2196.

79 Balthasar N, Dalgaard LT, Lee CE, Yu J, Funahashi $\mathrm{H}$, Williams T, Ferreira M, Tang V, McGovern RA, Kenny CD, Christiansen LM, Edelstein E, Choi B, Boss O, Aschkenasi C, Zhang CY, Mountjoy K, Kishi T, Elmquist JK, Lowell BB: Divergence of melanocortin pathways in the control of food intake and energy expenditure. Cell 2005;123:493-505.

$80 \mathrm{Xu} \mathrm{Y,} \mathrm{Wu} \mathrm{Z,} \mathrm{Sun} \mathrm{H,} \mathrm{Zhu} \mathrm{Y,} \mathrm{Kim} \mathrm{ER,} \mathrm{Lowell}$ $\mathrm{BB}$, Arenkiel BR, Xu Y, Tong Q: Glutamate mediates the function of melanocortin receptor 4 on Sim 1 neurons in body weight regulation. Cell Metab 2013;18:860-870. 
81 Shah BP, Vong L, Olson DP, Koda S, Krashes MJ, Ye C, Yang Z, Fuller PM, Elmquist JK, Lowell BB: MC4R-expressing glutamatergic neurons in the paraventricular hypothalamus regulate feeding and are synaptically connected to the parabrachial nucleus. Proc Natl Acad Sci USA 2014;111:13193-13198.

82 Kublaoui BM, Gemelli T, Tolson KP, Wang Y, Zinn AR: Oxytocin deficiency mediates hyperphagic obesity of Sim 1 haploinsufficient mice. Mol Endocrinol 2008;22:1723-1734.

83 Tolson KP, Gemelli T, Gautron L, Elmquist JK, Zinn AR, Kublaoui BM: Postnatal Sim1 deficiency causes hyperphagic obesity and reduced Mc4r and Oxytocin expression. J Neurosci 2010;30:3803-3812.

$84 \mathrm{Wu}$ Z, Xu Y, Zhu Y, Sutton AK, Zhao R, Lowell BB, Olson DP, Tong Q: An obligate role of oxytocin neurons in diet induced energy expenditure. PLoS One 2012;7:e45167.

85 Biag J, Huang Y, Gou L, Hintiryan H, Askarinam A, Hahn JD, Toga AW, Dong HW: Cytoand chemoarchitecture of the hypothalamic paraventricular nucleus in the C57BL/6J male mouse: a study of immunostaining and multiple fluorescent tract tracing. J Comp Neurol 2012;520:6-33.

86 Geerling JC, Shin JW, Chimenti PC, Loewy AD: Paraventricular hypothalamic nucleus: axonal projections to the brainstem. J Comp Neurol 2010;518:1460-1499.

87 Blevins JE, Morton GJ, Williams DL, Caldwell DW, Bastian LS, Wisse BE, Schwartz MW, Baskin DG: Forebrain melanocortin signaling enhances the hindbrain satiety response to CCK-8. Am J Physiol Regul Integr Comp Physiol 2009;296:R476-R484.

88 Blevins JE, Schwartz MW, Baskin DG: Evidence that paraventricular nucleus oxytocin neurons link hypothalamic leptin action to caudal brain stem nuclei controlling meal size. Am J Physiol Regul Integr Comp Physiol 2004;287:R87-R96.

89 Campos CA, Shiina H, Ritter RC: Central vagal afferent endings mediate reduction of food intake by melanocortin-3/4 receptor agonist. J Neurosci 2014;34:12636-12645.

90 Richardson J, Cruz MT, Majumdar U, Lewin A, Kingsbury KA, Dezfuli G, Vicini S, Verbalis JG, Dretchen KL, Gillis RA, Sahibzada N: Melanocortin signaling in the brainstem influences vagal outflow to the stomach. J Neurosci 2013;33:13286-13299.

91 Herbert H, Saper CB: Cholecystokinin-releasing, galanin-releasing, and corticotropinreleasing factor-like immunoreactive projections from the nucleus of the solitary tract to the parabrachial nucleus in the rat. J Comp Neurol 1990;293:581-598.

92 Voshart K, van der Kooy D: The organization of the efferent projections of the parabrachial nucleus of the forebrain in the rat: a retrograde fluorescent double-labeling study. Brain Res 1981;212:271-286.
93 Tokita K, Boughter JD Jr: Sweet-bitter and umami-bitter taste interactions in single parabrachial neurons in C57BL/6J mice. J Neurophysiol 2012;108:2179-2190.

94 Geerling JC, Loewy AD: Sodium deprivation and salt intake activate separate neuronal subpopulations in the nucleus of the solitary tract and the parabrachial complex. J Comp Neurol 2007;504:379-403.

95 Reilly S: The parabrachial nucleus and conditioned taste aversion. Brain Res Bull 1999; 48:239-254.

$96 \mathrm{Wu}$ Q, Clark MS, Palmiter RD: Deciphering a neuronal circuit that mediates appetite. Nature 2012;483:594-597.

97 Becskei C, Grabler V, Edwards GL, Riediger T, Lutz TA: Lesion of the lateral parabrachial nucleus attenuates the anorectic effect of peripheral amylin and CCK. Brain Res 2007; 1162:76-84.

98 DiPatrizio NV, Simansky KJ: Activating parabrachial cannabinoid $\mathrm{CB}_{1}$ receptors selectively stimulates feeding of palatable foods in rats. J Neurosci 2008;28:9702-9709.

$99 \mathrm{Wu}$ Q, Boyle MP, Palmiter RD: Loss of GABAergic signaling by AgRP neurons to the parabrachial nucleus leads to starvation. Cell 2009;137:1225-1234.

100 Carter ME, Soden ME, Zweifel LS, Palmiter $\mathrm{RD}$ : Genetic identification of a neural circuit that suppresses appetite. Nature 2013;503: 111-114.

101 Garfield AS, Li C, Madara JC, Shah BP, Webber E, Steger JS, Campbell JN, Gavrilova O, Lee CE, Olson DP, Elmquist JK, Tannous BA, Krashes MJ, Lowell BB: A neural basis for melanocortin-4 receptor-regulated appetite. Nat Neurosci 2015;18:863-871.

102 Takahashi YK, Roesch MR, Wilson RC, Toreson K, O'Donnell P, Niv Y, Schoenbaum $\mathrm{G}$ : Expectancy-related changes in firing of dopamine neurons depend on orbitofrontal cortex. Nat Neurosci 2011;14:1590-1597.

103 Bethus I, Tse D, Morris RG: Dopamine and memory: modulation of the persistence of memory for novel hippocampal NMDA receptor-dependent paired associates. J Neurosci 2010;30:1610-1618.

104 LaLumiere RT, Nawar EM, McGaugh JL: Modulation of memory consolidation by the basolateral amygdala or nucleus accumbens shell requires concurrent dopamine receptor activation in both brain regions. Learn Mem 2005;12:296-301.

105 Grillner S, Hellgren J, Ménard A, Saitoh K, Wikström MA: Mechanisms for selection of basic motor programs - roles for the striatum and pallidum. Trends Neurosci 2005; 28:364-370.

106 Seymour B, Daw N, Dayan P, Singer T, Dolan R: Differential encoding of losses and gains in the human striatum. J Neurosci 2007;27:4826-4831.

107 O’Doherty J, Dayan P, Schultz J, Deichmann R, Friston K, Dolan RJ: Dissociable roles of ventral and dorsal striatum in instrumental conditioning. Science 2004;304:452-454.
108 Daw ND, Kakade S, Dayan P: Opponent interactions between serotonin and dopamine. Neural Netw 2002;15:603-616.

109 Cohen JY, Amoroso MW, Uchida N: Serotonergic neurons signal reward and punishment on multiple timescales. Elife 2015; 4:e06346.

110 Berridge KC, Robinson TE, Aldridge JW: Dissecting components of reward: "liking," "wanting," and learning. Curr Opin Pharmacol 2009;9:65-73.

111 Saddoris MP, Cacciapaglia F, Wightman RM, Carelli RM: Differential dopamine release dynamics in the nucleus accumbens core and shell reveal complementary signals for error prediction and incentive motivation. J Neurosci 2015;35:11572-11582.

112 Hsu R, Taylor JR, Newton SS, Alvaro JD, Haile C, Han G, Hruby VJ, Nestler EJ, Duman RS: Blockade of melanocortin transmission inhibits cocaine reward. Eur J Neurosci 2005;21:2233-2242.

113 King CM, Hentges ST: Relative number and distribution of murine hypothalamic proopiomelanocortin neurons innervating distinct target sites. PLoS One 2011;6:e25864.

114 Dietrich MO, Bober J, Ferreira JG, Tellez LA, Mineur YS, Souza DO, Gao XB, Picciotto MR, Araujo I, Liu ZW, Horvath TL: AgRP neurons regulate development of dopamine neuronal plasticity and nonfood-associated behaviors. Nat Neurosci 2012;15:11081110.

115 Lindblom J, Opmane B, Mutulis F, Mutule I, Petrovska R, Klusa V, Bergström L, Wikberg JES: The MC4 receptor mediates $\alpha-\mathrm{MSH}$ induced release of nucleus accumbens dopamine. Neuroreport 2001;12:2155-2158.

116 Lippert RN, Ellacott KLJ, Cone RD: Genderspecific roles for the melanocortin-3 receptor in the regulation of the mesolimbic dopamine system in mice. Endocrinology 2014;155:1718-1727.

117 Pandit R, Omrani A, Luijendijk MC, de Vrind VA, Van Rozen AJ, Ophuis RJ, Garner K, Kallo I, Ghanem A, Liposits Z, Conzelmann KK, Vanderschuren LJ, la Fleur SE, Adan RA: Melanocortin 3 receptor signaling in midbrain dopamine neurons increases the motivation for food reward. Neuropsychopharmacology 2016;41:2241-2251.

118 Alvaro JD, Tatro JB, Quillan JM, Fogliano M, Eisenhard M, Lerner MR, Nestler EJ, Duman RS: Morphine down-regulates melanocortin-4 receptor expression in brain regions that mediate opiate addiction. Mol Pharmacol 1996;50:583-591.

119 Watabe-Uchida M, Zhu LS, Ogawa SK, Vamanrao A, Uchida N: Whole-brain mapping of direct inputs to midbrain dopamine neurons. Neuron 2012;74:858-873.

120 Pennartz CMA, Dasilva FHL, Groenewegen $\mathrm{HJ}$ : The nucleus accumbens as a complex of functionally distinct neuronal ensembles: an integration of behavioral, electrophysiological and anatomical data. Prog Neurobiol 1994;42:719-761.
The Role of the Melanocortin System in Metabolic Disease
Neuroendocrinology 2017;104:330-346 DOI: $10.1159 / 000450649$ 
121 Sulzer D: How addictive drugs disrupt presynaptic dopamine neurotransmission. Neuron 2011;69:628-649.

122 Surmeier DJ, Ding J, Day M, Wang Z, Shen W: D1 and D2 dopamine-receptor modulation of striatal glutamatergic signaling in striatal medium spiny neurons. Trends Neurosci 2007;30:228-235.

123 Bromberg-Martin ES, Matsumoto M, Hikosaka O: Dopamine in motivational control: rewarding, aversive, and alerting. Neuron 2010;68:815-834.

124 Shen W, Flajolet M, Greengard P, Surmeier DJ: Dichotomous dopaminergic control of striatal synaptic plasticity. Science 2008;321: 848-851.

125 Mirenowicz J, Schultz W: Importance of unpredictability for reward responses in primate dopamine neurons. J Neurophysiol 1994;72:1024-1027.

126 Roitman MF, Wheeler RA, Wightman RM, Carelli RM: Real-time chemical responses in the nucleus accumbens differentiate rewarding and aversive stimuli. Nat Neurosci 2008; 11:1376-1377.

127 Lobo MK, Covington HE 3rd, Chaudhury D, Friedman AK, Sun HS, Damez-Werno D, Dietz DM, Zaman S, Koo JW, Kennedy PJ, Mouzon E, Mogri M, Neve RL, Deisseroth K, Han MH, Nestler EJ: Cell type-specific loss of BDNF signaling mimics optogenetic control of cocaine reward. Science 2010;330: 385-390.

128 Ferguson SM, Eskenazi D, Ishikawa M, Wanat MJ, Phillips PEM, Dong Y, Roth BL, Neumaier JF: Transient neuronal inhibition reveals opposing roles of indirect and direct pathways in sensitization. Nat Neurosci 2011;14:22-24.

129 Kravitz AV, Kreitzer AC: Striatal mechanisms underlying movement, reinforcement, and punishment. Physiology 2012;27: 167-177.

130 Hikida T, Kimura K, Wada N, Funabiki K, Nakanishi S: Distinct roles of synaptic transmission in direct and indirect striatal pathways to reward and aversive behavior. Neuron 2010;66:896-907.

131 Lüthi A, Lüscher C: Pathological circuit function underlying addiction and anxiety disorders. Nat Neurosci 2014;17:1635-1643.

132 Bock R, Shin JH, Kaplan AR, Dobi A, Markey E, Kramer PF, Gremel CM, Christensen $\mathrm{CH}$, Adrover MF, Alvarez VA: Strengthening the accumbal indirect pathway promotes resilience to compulsive cocaine use. Nat Neurosci 2013;16:632-638.

133 Kravitz AV, Freeze BS, Parker PRL, Kay K, Thwin MT, Deisseroth K, Kreitzer AC: Regulation of parkinsonian motor behaviours by optogenetic control of basal ganglia circuitry. Nature 2010;466:622-626.

134 Kravitz AV, Tye LD, Kreitzer AC: Distinct roles for direct and indirect pathway striatal neurons in reinforcement. Nat Neurosci 2012;15:816-818.
135 Cooper SJ, Al-Naser HA, Clifton PG: The anorectic effect of the selective dopamine $\mathrm{D}_{1}$-receptor agonist A-77636 determined by meal pattern analysis in free-feeding rats. Eur J Pharmacol 2006;532:253-257.

136 Williams DL, Grill HJ, Weiss SM, Baird JP, Kaplan JM: Behavioral processes underlying the intake suppressive effects of melanocortin 3/4 receptor activation in the rat. Psychopharmacology (Berl) 2002;161:47-53.

137 Panaro BL, Cone RD: Melanocortin-4 receptor mutations paradoxically reduce preference for palatable foods. Proc Natl Acad Sci USA 2013;110:7050-7055.

138 Vaughan CH, Moore MC, Haskell-Luevano C, Rowland NE: Meal patterns and foraging in melanocortin receptor knockout mice. Physiol Behav 2005;84:129-133.

139 Atalayer D, Robertson KL, Haskell-Luevano C, Andreasen A, Rowland NE: Food demand and meal size in mice with single or combined disruption of melanocortin type 3 and 4 receptors. Am J Physiol Regul Integr Comp Physiol 2010;298:R1667-R1674.

140 Cui HX, Mason BL, Lee C, Nishi A, Elmquist JK, Lutter M: Melanocortin 4 receptor signaling in dopamine 1 receptor neurons is required for procedural memory learning. Physiol Behav 2012;106:201-210.

141 Cui H, Lutter M: The expression of MC4Rs in D1R neurons regulates food intake and locomotor sensitization to cocaine. Genes Brain Behav 2013;12:658-665.

142 Schultz W, Dayan P, Montague PR: A neural substrate of prediction and reward. Science 1997;275:1593-1599.

143 Brooks AM, Berns GS: Aversive stimuli and loss in the mesocorticolimbic dopamine system. Trends Cogn Sci 2013;17:281-286.

144 Schwartenbeck P, FitzGerald TH, Mathys C, Dolan R, Friston K: The dopaminergic midbrain encodes the expected certainty about desired outcomes. Cereb Cortex 2015;25: 3434-3445.

145 Seeley RJ, Berridge KC: The hunger games. Cell 2015;160:805-806.

146 DiLeone RJ: The influence of leptin on the dopamine system and implications for ingestive behavior. Int J Obes (Lond) 2009; 33(suppl 2):S25-S29.

147 Farooqi IS, Bullmore E, Keogh J, Gillard J, O'Rahilly S, Fletcher PC: Leptin regulates striatal regions and human eating behavior. Science 2007;317:1355.

148 Figlewicz DP, Sipols AJ: Energy regulatory signals and food reward. Pharmacol Biochem Behav 2010;97:15-24.

149 Chalmers JP, Pilowsky PM, Minson JB, Kapoor V, Mills E, West MJ: Central serotonergic mechanisms in hypertension. Am J Hypertens 1988;1:79-83.

150 Colombari E, Sato MA, Cravo SL, Bergamaschi CT, Campos RR Jr, Lopes OU: Role of the medulla oblongata in hypertension. Hypertension 2001;38:549-554.
151 Talman WT: Cardiovascular regulation and lesions of the central nervous system. Ann Neurol 1985;18:1-13.

152 da Silva AA, Kuo JJ, Hall JE: Role of hypothalamic melanocortin 3/4-receptors in mediating chronic cardiovascular, renal, and metabolic actions of leptin. Hypertension 2004;43:1312-1317.

153 do Carmo JM, Tallam LS, Roberts JV, Brandon EL, Biglane J, da Silva AA, Hall JE: Impact of obesity on renal structure and function in the presence and absence of hypertension: evidence from melanocortin-4 receptor-deficient mice. Am J Physiol Regul Integr Comp Physiol 2009;297:R803-R812.

154 Greenfield JR, Miller JW, Keogh JM, Henning E, Satterwhite JH, Cameron GS, Astruc B, Mayer JP, Brage S, See TC, Lomas DJ, O'Rahilly S, Farooqi IS: Modulation of blood pressure by central melanocortinergic pathways. N Engl J Med 2009;360:44-52.

155 Farooqi IS, O’Rahilly S: Monogenic human obesity syndromes. Recent Prog Horm Res 2004;59:409-424.

156 Martinelli CE, Keogh JM, Greenfield JR, Henning E, van der Klaauw AA, Blackwood A, O’Rahilly S, Roelfsema F, Camacho-Hübner C, Pijl H, Farooqi IS: Obesity due to melanocortin 4 receptor (MC4R) deficiency is associated with increased linear growth and final height, fasting hyperinsulinemia, and incompletely suppressed growth hormone secretion. J Clin Endocr Metab 2011; 96:E181-E188.

157 Maier T, Hoyer J: Modulation of blood pressure by central melanocortinergic pathways. Nephrol Dial Transplant 2010;25:674-677.

158 Greenfield JR: Melanocortin signalling and the regulation of blood pressure in human obesity. J Neuroendocrinol 2011;23:186193.

159 Ni XP, Butler AA, Cone RD, Humphreys $\mathrm{MH}$ : Central receptors mediating the cardiovascular actions of melanocyte stimulating hormones. J Hypertens 2006;24:22392246.

160 Dubinion JH, da Silva AA, Hall JE: Enhanced blood pressure and appetite responses to chronic central melanocortin-3/4 receptor blockade in dietary-induced obesity. J Hypertens 2010;28:1466-1470.

161 do Carmo JM, da Silva AA, Rushing JS, Hall JE: Activation of the central melanocortin system contributes to the increased arterial pressure in obese Zucker rats. Am J Physiol Regul Integr Comp Physiol 2012;302:R561R567.

162 Carlyle M, Jones OB, Kuo JJ, Hall JE: Chronic cardiovascular and renal actions of leptin - role of adrenergic activity. Hypertension 2002;39:496-501.

163 do Carmo JM, da Silva AA, Cai ZW, Lin SY, Dubinion JH, Hall JE: Control of blood pressure, appetite, and glucose by leptin in mice lacking leptin receptors in proopiomelanocortin neurons. Hypertension 2011;57:918926. 
164 Tallam LS, da Silva AA, Hall JE: Melanocortin-4 receptor mediates chronic cardiovascular and metabolic actions of leptin. Hypertension 2006;48:58-64.

165 do Carmo JM, da Silva AA, Wang Z, Freeman NJ, Alsheik AJ, Adi A, Hall JE: Regulation of blood pressure, appetite, and glucose by leptin after inactivation of insulin receptor substrate 2 signaling in the entire brain or in proopiomelanocortin neurons. Hypertension 2016;67:378-386.

166 Li YF, Jackson KL, Stern JE, Rabeler B, Patel KP: Interaction between glutamate and GABA systems in the integration of sympathetic outflow by the paraventricular nucleus of the hypothalamus. Am J Physiol Heart Circ Physiol 2006;291:H2847-H2856.

167 Li P, Cui BP, Zhang LL, Sun HJ, Liu TY, Zhu GQ: Melanocortin 3/4 receptors in paraventricular nucleus modulate sympathetic outflow and blood pressure. Exp Physiol 2013; 98:435-443.

168 Tai MH, Weng WT, Lo WC, Chan JY, Lin CJ, Lam HC, Tseng CJ: Role of nitric oxide in $\alpha$-melanocyte-stimulating hormone-induced hypotension in the nucleus tractus solitarii of the spontaneously hypertensive rats. J Pharmacol Exp Ther 2007;321:455461.

169 Pavia JM, Schiöth HB, Morris MJ: Role of MC4 receptors in the depressor and bradycardic effects of $\alpha-\mathrm{MSH}$ in the nucleus tractus solitarii of the rat. Neuroreport 2003;14: 703-707.

170 Eerola K, Rinne P, Penttinen AM, Vähätalo L, Savontaus M, Savontaus E: $\alpha-M S H$ overexpression in the nucleus tractus solitarius decreases fat mass and elevates heart rate. J Endocrinol 2014;222:123-136.

171 Iwasa M, Kawabe K, Sapru HN: Activation of melanocortin receptors in the intermediolateral cell column of the upper thoracic cord elicits tachycardia in the rat. Am J Physiol Heart Circ Physiol 2013;305:H885H893.

172 Huszar D, Lynch CA, Fairchild-Huntress V, Dunmore JH, Fang Q, Berkemeier LR, Gu W, Kesterson RA, Boston BA, Cone RD, Smith FJ, Campfield LA, Burn P, Lee F: Targeted disruption of the melanocortin-4 receptor results in obesity in mice. Cell 1997; 88:131-141.

173 Fan W, Boston BA, Kesterson RA, Hruby VJ, Cone RD: Role of melanocortinergic neurons in feeding and the agouti obesity syndrome. Nature 1997;385:165-168.

174 Obici S, Feng ZH, Tan JZ, Liu LS, Karkanias G, Rossetti L: Central melanocortin receptors regulate insulin action. J Clin Invest 2001;108:1079-1085.

175 Lubrano-Berthelier C, Le Stunff C, Bougnères $\mathrm{P}$, Vaisse $\mathrm{C}$ : A homozygous null mutation delineates the role of the melanocortin-4 receptor in humans. J Clin Endocrinol Metab 2004;89:2028-2032.
176 Rossi J, Balthasar N, Olson D, Scott M, Berglund E, Lee CE, Choi MJ, Lauzon D, Lowell BB, Elmquist JK: Melanocortin-4 receptors expressed by cholinergic neurons regulate energy balance and glucose homeostasis. Cell Metab 2011;13:195-204.

177 Ahrén B: Autonomic regulation of islet hormone secretion - implications for health and disease. Diabetologia 2000;43:393-410.

178 Berglund ED, Liu T, Kong X, Sohn JW, Vong L, Deng Z, Lee CE, Lee S, Williams KW, Olson DP, Scherer PE, Lowell BB, Elmquist JK: Melanocortin 4 receptors in autonomic neurons regulate thermogenesis and glycemia. Nat Neurosci 2014;17:911-913.

179 Mimee A, Ferguson AV: Glycemic state regulates melanocortin, but not nesfatin-1, responsiveness of glucose-sensing neurons in the nucleus of the solitary tract. Am J Physiol Regul Integr Comp Physiol 2015;308: R690-R699.

180 Pocai A, Morgan K, Buettner C, GutierrezJuarez R, Obici S, Rossetti L: Central leptin acutely reverses diet-induced hepatic insulin resistance. Diabetes 2005;54:3182-3189.

181 da Silva AA, do Carmo JM, Freeman JN, Tallam LS, Hall JE: A functional melanocortin system may be required for chronic CNSmediated antidiabetic and cardiovascular actions of leptin. Diabetes 2009;58:17491756.

182 Hill JW, Elias CF, Fukuda M, Williams KW, Berglund ED, Holland WL, Cho YR, Chuang JC, Xu Y, Choi M, Lauzon D, Lee CE, Coppari R, Richardson JA, Zigman JM, Chua S, Scherer PE, Lowell BB, Brüning JC, Elmquist JK: Direct insulin and leptin action on pro-opiomelanocortin neurons is required for normal glucose homeostasis and fertility. Cell Metab 2010;11:286-297.

183 Faulkner L, Dowling A, Stuart R, Nillni E, Hill J: Reduced melanocortin production causes sexual dysfunction in male mice with POMC neuronal insulin and leptin insensitivity. Endocrinology 2015;156:13721385.

184 Berglund ED, Vianna CR, Donato J, Kim $\mathrm{MH}$, Chuang JC, Lee CE, Lauzon DA, Lin P, Brule LJ, Scott MM, Coppari R, Elmquist JK: Direct leptin action on POMC neurons regulates glucose homeostasis and hepatic insulin sensitivity in mice. J Clin Invest 2012;122: 1000-1009.

185 Huo L, Gamber K, Greeley S, Silva J, Huntoon N, Leng XH, Bjørbaek C: Leptindependent control of glucose balance and locomotor activity by POMC neurons. Cell Metab 2009;9:537-547.

186 Coleman DL: Effects of parabiosis of obese with diabetes and normal mice. Diabetologia 1973;9:294-298.

187 Gonçalves GH, Li W, Garcia AV, Figueiredo MS, Bjørbaek C: Hypothalamic agouti-related peptide neurons and the central melanocortin system are crucial mediators of leptin's antidiabetic actions. Cell Rep 2014; 7:1093-1103.
188 Morgan DA, McDaniel LN, Yin T, Khan M, Jiang JW, Acevedo MR, Walsh SA, Ponto LLB, Norris AW, Lutter M, Rahmouni K, Cui HX: Regulation of glucose tolerance and sympathetic activity by MC4R signaling in the lateral hypothalamus. Diabetes 2015;64: 1976-1987.

189 Rossi J, Balthasar N, Olson D, Scott M, Berglund E, Lee CE, Choi MJ, Lauzon D, Lowell BB, Elmquist JK: Melanocortin-4 receptors expressed by cholinergic neurons regulate energy balance and glucose homeostasis. Cell Metab 2011;13:195-204.

190 Lute B, Jou W, Lateef DM, Goldgof M, Xiao C, Piñol RA, Kravitz AV, Miller NR, Huang YG, Girardet C, Butler AA, Gavrilova O, Reitman ML: Biphasic effect of melanocortin agonists on metabolic rate and body temperature. Cell Metab 2014;20:333-345.

191 Xu Y, Kim ER, Fan S, Xia Y, Xu Y, Huang C, Tong Q: Profound and rapid reduction in body temperature induced by the melanocortin receptor agonists. Biochem Biophys Res Commun 2014;451:184-189.

192 Dodd GT, Decherf S, Loh K, Simonds SE, Wiede F, Balland E, Merry TL, Münzberg H, Zhang ZY, Kahn BB, Neel BG, Bence KK, Andrews ZB, Cowley MA, Tiganis T: Leptin and insulin act on POMC neurons to promote the browning of white fat. Cell 2015; 160:88-104.

193 Haynes WG, Morgan DA, Djalali A, Sivitz WI, Mark AL: Interactions between the melanocortin system and leptin in control of sympathetic nerve traffic. Hypertension 1999;33:542-547.

194 Enriori PJ, Sinnayah P, Simonds SE, Garcia Rudaz C, Cowley MA: Leptin action in the dorsomedial hypothalamus increases sympathetic tone to brown adipose tissue in spite of systemic leptin resistance. J Neurosci 2011;31:12189-12197.

195 Bamshad M, Song CK, Bartness TJ: CNS origins of the sympathetic nervous system outflow to brown adipose tissue. Am J Physiol 1999;276(pt 2):R1569-R1578.

196 Rothwell NJ, Stock MJ: Effects of denervating brown adipose tissue on the responses to cold, hyperphagia and noradrenaline treatment in the rat. J Physiol 1984;355:457-463.

197 Lowell BB, Flier JS: Brown adipose tissue, $\beta_{3}$ adrenergic receptors, and obesity. Annu Rev Med 1997;48:307-316.

198 McAninch EA, Bianco AC: Thyroid hormone signaling in energy homeostasis and energy metabolism. Ann NY Acad Sci 2014; 1311:77-87.

199 Fekete C, Légrádi G, Mihály E, Huang QH, Tatro JB, Rand WM, Emerson CH, Lechan RM: $\alpha$-Melanocyte-stimulating hormone is contained in nerve terminals innervating thyrotropin-releasing hormone-synthesizing neurons in the hypothalamic paraventricular nucleus and prevents fasting-induced suppression of prothyrotropin-releasing hormone gene expression. J Neurosci 2000;20:1550-1558. 
200 Harris M, Aschkenasi C, Elias CF, Chandrankunnel A, Nillni EA, Bjørbaek C, Elmquist JK, Flier JS, Hollenberg AN: Transcriptional regulation of the thyrotropinreleasing hormone gene by leptin and melanocortin signaling. J Clin Invest 2001; 107:111-120.

201 Kim MS, Small CJ, Stanley SA, Morgan DGA, Seal LJ, Kong WM, Edwards CMB, Abusnana S, Sunter D, Ghatei MA, Bloom SR: The central melanocortin system affects the hypothalamo-pituitary thyroid axis and may mediate the effect of leptin. J Clin Invest 2000;105:1005-1011.

202 Farooqi IS, Keogh JM, Yeo GSH, Lank EJ, Cheetham T, O'Rahilly S: Clinical spectrum of obesity and mutations in the melanocortin 4 receptor gene. N Engl J Med 2003;348: 1085-1095.

203 Vella KR, Ramadoss P, Lam FS, Harris JC, Ye FD, Same PD, O’Neill NF, Maratos-Flier E, Hollenberg AN: NPY and MC4R signaling regulate thyroid hormone levels during fasting through both central and peripheral pathways. Cell Metab 2011;14:780-790.

204 Bjursell M, Gerdin AK, Lelliott CJ, Egecioglu E, Elmgren A, Törnell J, Oscarsson J, Bohlooly-Y M: Acutely reduced locomotor activity is a major contributor to Western diet-induced obesity in mice. Am J Physiol Endocrinol Metab 2008;294:E251-E260.

205 Keesey RE, Swiergiel AH, Corbett SW: Contribution of spontaneous activity to daily energy-expenditure of adult obese and lean Zucker rats. Physiol Behav 1990;48:327331.

206 Ahlenius S, Hillegaart V, Thorell G, Magnusson O, Fowler CJ: Suppression of exploratory locomotor-activity and increase in dopamine turnover following the local application of $c i s$-flupentixol into limbic projection areas of the rat striatum. Brain Res 1987;402: 131-138.
207 Jones GH, Robbins TW: Differential effects of mesocortical, mesolimbic, and mesostriatal dopamine depletion on spontaneous, conditioned, and drug-induced locomotor activity. Pharmacol Biochem Behav 1992;43: 887-895.

208 Kiehn O, Dougherty K: Locomotion: circuits and physiology; in Pfaff DW (ed): Neuroscience in the 21st Century: From Basic to Clinical. New York, Springer, 2013, pp 1209 1236.

209 Yoshida M, Taniguchi Y: Projection of proopiomelanocortin neurons from the rat arcuate nucleus to the midbrain central gray as demonstrated by double staining with retrograde labeling and immunohistochemistry. Arch Histol Cytol 1988;51:175-183.

210 Ribeiro AC, Ceccarini G, Dupré C, Friedman JM, Pfaff DW, Mark AL: Contrasting effects of leptin on food anticipatory and total locomotor activity. PLoS One 2011; 6:e23364.

211 Coppari R, Ichinose M, Lee CE, Pullen AE, Kenny CD, McGovern RA, Tang V, Liu SM, Ludwig T, Chua SC Jr, Lowell BB, Elmquist JK: The hypothalamic arcuate nucleus: a key site for mediating leptin's effects on glucose homeostasis and locomotor activity. Cell Metab 2005;1:63-72.

212 Ste Marie L, Miura GI, Marsh DJ, Yagaloff K, Palmiter RD: A metabolic defect promotes obesity in mice lacking melanocortin-4 receptors. Proc Natl Acad Sci USA 2000;97:12339-12344.

213 Sutton GM, Perez-Tilve D, Nogueiras R, Fang JD, Kim JK, Cone RD, Gimble JM, Tschöp MH, Butler AA: The melanocortin-3 receptor is required for entrainment to meal intake. J Neurosci 2008;28:12946-12955.
214 Dietrich MO, Zimmer MR, Bober J, Horvath TL: Hypothalamic Agrp neurons drive stereotypic behaviors beyond feeding. Cell 2015;160:1222-1232.

215 Girardet C, Butler AA: Neural melanocortin receptors in obesity and related metabolic disorders. Biochim Biophys Acta 2014;1842: 482-494.

216 Grayson BE, Seeley RJ, Sandoval DA: Wired on sugar: the role of the CNS in the regulation of glucose homeostasis. Nat Rev Neurosci $2013 ; 14: 24-37$.

217 Mark AL, Correia M, Morgan DA, Shaffer RA, Haynes WG: State-of-the-art-lecture: obesity-induced hypertension: new concepts from the emerging biology of obesity. Hypertension 1999;33(pt 2):537-541.

218 Royalty JE, Konradsen G, Eskerod O, Wulff BS, Hansen BS: Investigation of safety, tolerability, pharmacokinetics, and pharmacodynamics of single and multiple doses of a long-acting $\alpha$-MSH analog in healthy overweight and obese subjects. J Clin Pharmacol 2014;54:394-404.

219 Chen M, Wang J, Dickerson KE, Kelleher J, Xie T, Gupta D, Lai EW, Pacak K, Gavrilova O, Weinstein LS: Central nervous system imprinting of the $G$ protein $\mathrm{G}_{\mathrm{s}} \alpha$ and its role in metabolic regulation. Cell Metab 2009;9: 548-555.

220 Li YQ, Shrestha Y, Pandey M, Chen M, Kablan A, Gavrilova O, Offermanns S, Weinstein LS: $G_{q / 11} \alpha$ and $G_{s} \alpha$ mediate distinct physiological responses to central melanocortins. J Clin Invest 2016;126:40-49.

221 Chen M, Berger A, Kablan A, Zhang JD, Gavrilova O, Weinstein LS: $G_{s} \alpha$ deficiency in the paraventricular nucleus of the hypothalamus partially contributes to obesity associated with $\mathrm{G}_{\mathrm{s}} \alpha$ mutations. Endocrinology 2012;153:4256-4265. 